\title{
ARTICLE
}

\section{Sustainable Development and Its Discontents}

\author{
John C. Dernbach* and Federico Cheever**
}

\begin{abstract}
Sustainable development (or sustainability) is a decision-making framework for maintaining and achieving human well-being, both in the present and into the future. The framework requires both consideration and the achievement of environmental protection, social justice and economic development. In that framework, environmental protection must be integrated into decisions about social and economic development, and social justice and economic viability must be integrated into decisions about environmental quality.

As sustainable development has grown in prominence, its critics have become more numerous and more vocal. Three major lines of criticism are that the term is 'too boring' to command public attention, 'too vague' to provide guidance, and 'too late' to address the world's problems. Critics suggest goals such as abundance, environmental integrity, and resilience. Beginning with the international agreements that have shaped the concept of sustainable development, this article provides a functional and historical analysis of the meaning of sustainable development. It then analyzes and responds to each of the above criticisms. It argues that the critics, understood constructively, suggest ways of strengthening this framework, but do not provide a compelling alternative. The challenge for lawyers, lawmakers, and others is to use and improve the sustainability framework to make better decisions.
\end{abstract}

Keywords: Sustainable development, Sustainability, Integrated decision making, Rio Declaration, Resilience

\section{INTRODUCTION}

Our task is to create a society which is sustainable and which will give the fullest possible satisfaction to its members. Such a society by definition would depend not on expansion but on stability. This does not mean to say that it would be stagnant - indeed it could

* Widener University, Commonwealth Law School, Harrisburg, PA (United States).

Email: jcdernbach@widener.edu.

Thanks to Ben Barros, Ira Feldman, Diane Henkels, and Dan Tarlock for their comments on an earlier draft. Thanks also to the Environmental Law Institute (ELI) and the participants in an ELI webinar, as well as the Environmental Law Collaborative and participants in a collaborative workshop, for their help in developing many of the ideas in this article.

* University of Denver, Sturm College of Law, Denver, CO (United States).

Email: fcheever@law.du.edu.

Thanks to Chris Stevens, Denver Sturm College of Law Class of 2013, and Taylor Scherer, Denver Sturm College of Law Class of 2014, for research assistance. Special thanks to Robin Kundis Craig and Melinda Harm Benson for their critique of earlier drafts and the inspiration their work provides. 
well afford more variety than does the state of uniformity at present being imposed by the pursuit of technological efficiency. We believe that the stable society ... as well as removing the sword of Damocles which hangs over the heads of future generations, is much more likely than the present one to bring the peace and fulfillment which hitherto have been regarded, sadly, as utopian.

Edward Goldsmith \& Robert Allen ${ }^{1}$

Rarely does a concept so swiftly and powerfully infuse such a broad range of human endeavour as has 'sustainability'. Sustainable development (or sustainability ${ }^{2}$ ) has become a touchstone in law, ${ }^{3}$ education, ${ }^{4}$ and business. ${ }^{5}$ It has unleashed an extraordinary range of creativity in each of those realms. Based on its current prevalence in book titles, corporate and government policies, agreements, declarations and conference titles, the concept will remain prominent for decades to come. ${ }^{6}$

Not surprisingly, the rise of the concept of sustainability has inspired criticism. As the concept has become ubiquitous, its critics have become more numerous and more vocal. Currently, these critics fall into three broad categories, discussed in detail in Part 3 of this article. Firstly, some believe the concept is not sufficiently attractive to inspire the mobilization of human resources necessary to meet the current crisis.

1 E. Goldsmith \& R. Allen, 'A Blueprint for Survival', The Ecologist, 1 Jan. 1972, para. 166, available at: http://www.edwardgoldsmith.org/1125/introduction-the-need-for-change. The article occupied the entire first issue of the second volume of The Ecologist, and was later published as a book by Penguin (1972) in response to popular demand. The piece was written in advance of the 1972 United Nations (UN) Conference on the Human Environment in Stockholm - the world's first environmental summit. Edward Goldsmith and Robert Allen are the principal authors, with contributions from Michael Allaby, John Davoll and Sam Lawrence.

2 This article uses the terms interchangeably, although we recognize that the terms may connote somewhat different meanings in other contexts; for more detail, see Part 2 below.

3 The Environmental Law Institute (ELI) has published 3 separate sustainability reviews of United States (US) law and policy: J. Dernbach et al., Acting as if Tomorrow Matters: Accelerating the Transition to Sustainability (ELI, 2012); J. Dernbach (ed.), Agenda for a Sustainable America (ELI, 2009); J. Dernbach (ed.), Stumbling Toward Sustainability (ELI, 2002). Fred Cheever co-authored Acting as if Tomorrow Matters and contributed a chapter to Agenda for a Sustainable America: F. Cheever \& W. Scott, 'Sustainable Forestry: Moving from Concept to Consistent Practice', in Dernbach, Agenda for a Sustainable America, ibid., pp. 285-302. Sustainable development is also widely applied in international law: e.g., G. Bándi, M. Szabo \& A. Szalai, Sustainability, Law and Public Choice (Europa Law, 2014); M. Cordonier Segger \& A. Khalfan, Sustainable Development Law: Principles, Practices, and Prospects (Oxford University Press, 2004). See also nn. 46-50 below and accompanying text.

4 See, e.g., W. Calder \& J. Dautremont-Smith, 'Higher Education: More and More Laboratories for Inventing a Sustainable Future', in Dernbach, Agenda for a Sustainable America, ibid., at pp. 93-107; C. Federico \& J. Cloud, 'Kindergarten Through Twelfth Grade Education: Fragmentary Progress in Equipping Students to Think and Act in a Challenging World', in Dernbach, Agenda for a Sustainable America, ibid., at pp. 109-27; S. Lavey \& W. Lavey, 'Sustainability U' (2015) 32(2) The Environmental Forum, pp. 32-6.

5 See, e.g., W. Blackburn, The Sustainability Handbook: The Complete Management Guide to Achieving Social, Economic, and Environmental Responsibility (ELI, 2007); I. Feldman, 'Business and Industry: Transition to Sustainability', in Dernbach, Agenda for a Sustainable America, n. 3 above, at pp. 71-91; W. Thomas, Business and Industry, in Dernbach, Stumbling Toward Sustainability, n. 3 above, at pp. 541-92.

6 Plugging the word 'sustainability' into the Google Ngram Viewer (which charts the frequency of the use of words and phrases in books digitized in the Google Books Project) shows the dramatic rise in usage of the term since the late 1970s; 'sustainable development' has followed a similar, if slightly less spectacular, trajectory: see Google Books, Ngram Viewer results at: http://tinyurl.com/nvjttm8. This rapid rise led xkcd (a webcomic of Romance, Sarcasm, Math and Language) to extrapolate a world in which, by 2061, 'sustainable' occurs on average once per sentence and, by 2109 , 'all sentences are just the word 'sustainable' repeated over and over again': 'Sustainable', available at: https://xkcd.com/1007. 
They assert that sustainability is 'too boring' to inspire the change we need. These critics suggest 'thriving', 'abundance' or other, more exciting alternatives.

Secondly, others feel the concept is 'too vague' or ill-defined to be useful because they see it being applied without serious attention to environmental protection or environmental integrity. They say that sustainability can easily be manipulated to support 'greenwashing' - inaccurate or exaggerated claims about a company's performance.

Thirdly, there are those who believe that the prospect for a human future on planet Earth is so dire that the idea of anything being sustainable is illusory - a form of denial - and must be discarded. Motivated especially by the growing reality of climate disruption, these critics assert that it is 'too late' for the concept of sustainability to be useful, that we must now speak about 'surviving not thriving'. Many argue that 'resilience' should replace sustainability.

To be sure, there are other critics, including those who see sustainability as part of an international conspiracy to weaken property rights. ${ }^{7}$ The three lines of critical argument analyzed here, however, appear to be the most prevalent. While none of the three arguments is entirely without justification, each misconstrues the fundamental nature of the concept of sustainability. This article explains the origin and purpose of sustainable development or sustainability, and then applies that understanding to respond to each of these groups of critics.

Part 2 of this article provides a functional and historical analysis of the meaning of sustainable development and focuses on the concept as a framework for making decisions. It is the history of the concept, and the practice that it has inspired, that gives it meaning. As explained in Part 2, the sustainable development framework is intended to provide an effective response to the two global challenges of increasing environmental degradation and widespread extreme poverty. These problems occur when environmental protection and development decisions are made separately. Correspondingly, the central idea of sustainable development is the integration of environmental and development decision making. Its purpose is to maintain and improve human well-being for current and future generations.

Sustainability is not an academic concept or a marketing gimmick; it is a decisionmaking framework that reflects abundant real world experience. The primary challenge is not to better define our environmental or social goals, although that is important. Rather, the primary challenge is to make better decisions. This framework provides a way of responding constructively to the challenges of the 'too boring', 'too vague', and 'too late' critics.

Part 3 addresses each of these objections to sustainability in turn. Taken together, these critics focus on various popular understandings or versions of sustainability, but not on the understanding of sustainable development (or sustainability) described in Part 2. While their suggestions - greater attention to a more positive future, genuine environmental protection, and resilience - are not necessarily in harmony, each can

7 See n. 128 below. 
be accommodated within the sustainable development framework. In varying ways, moreover, each of them should be accommodated in that framework.

The critics do not succeed in mounting a compelling case against the concept of sustainable development, but their arguments do provide an opportunity to explore the concept, its power, and its limitations. This is important because sustainable development has become the internationally accepted framework for maintaining and improving human well-being. In 1992, at the United Nations (UN) Conference on Environment and Development (UNCED or Rio Earth Summit), the world's nations agreed to a 'global partnership for sustainable development', explaining that 'integration of environment and development concerns and greater attention to them will lead to the fulfilment of basic needs, improved living standards for all, better protected and managed ecosystems and a safer, more prosperous future'. ${ }^{8}$ In 2012, at the UN Conference on Sustainable Development (Rio+20), the world's nations agreed to 'renew our commitment to sustainable development and to ensuring the promotion of an economically, socially and environmentally sustainable future for our planet and for present and future generations. ${ }^{9}$ At that same conference, they committed to a process for the adoption of Sustainable Development Goals for all countries. ${ }^{10}$

This understanding of the central role of sustainable development is not limited to governments. In June 2015, Pope Francis I issued an encyclical on the environment and climate change that is framed in significant part by sustainable development: 'The urgent challenge to protect our common home includes a concern to bring the whole human family together to seek a sustainable and integral development'. ${ }^{11}$

Sustainable development is an important idea; indeed, it may be one of the most important ideas to come out of the $20^{\text {th }}$ century. It deserves this claim because it provides an overall framework for humans to live in harmony with nature, rather than at the expense of nature, as we have for centuries. Some authors describe it as an idea or principle of the same level of fundamental importance as freedom, equality, and justice. ${ }^{12}$ In democracies in which governmental and business decision makers respond to the market of ideas and information, we need a reasonably accurate public understanding of sustainability to move those decision makers in a more sustainable direction. Unless a wide variety of people and organizations properly understand sustainability and demand better decisions, the prospect of more sustainable decisions is unlikely.

8 UN Sustainable Development, 'Agenda 21', adopted at UNCED, Rio de Janeiro (Brazil), 3-14 June 1992, UN Doc. A/CONF.151.26, 1992, para. 1.1, available at: https://sustainabledevelopment.un.org/ content/documents/Agenda21.pdf.

9 UN Conference on Sustainable Development, The Future We Want, UN Doc. A/66/L.56, 24 July 2012 , para. 1, available at: http://daccess-dds-ny.un.org/doc/UNDOC/LTD/N12/436/88/PDF/N1243688. pdf? OpenElement.

10 Ibid., at paras 245-51. The UN is scheduled to adopt 17 Sustainable Development Goals (SDGs) at a special meeting to be held on 25-27 Sept. 2015. At the time of writing, they are still in draft form: see UN SDGs, available at: https://sustainabledevelopment.un.org/topics/sustainabledevelopmentgoals.

11 Pope Francis I, Laudato Si, (2015), at para. 13, available at: http://w2.vatican.va/content/dam/ francesco/pdf/encyclicals/documents/papa-francesco_20150524_enciclica-laudato-si_en.pdf.

12 K. Bosselmann, The Principle of Sustainability: Transforming Law and Governance (Ashgate, 2008), p. 57. 
Sustainable development is a normative conceptual framework; it is not a legal framework. Yet, just as other normative ideas such as freedom, equality, and justice have been written into law, so sustainable development is being written into law. Sustainability provides a framework for writing, modifying, and implementing laws, and for developing appropriate institutions and institutional arrangements, to further sustainable development in specific places and specific contexts. This includes constitutions, statutes, and other forms of public law. Sustainable development is also employed in private law, including such aspects as certification, auditing, labelling, and reporting programmes for sustainability, which tend to be enforced through a variety of contractual and related arrangements. ${ }^{13}$ In addition, many public sector and private sector clients are seeking legal help to meet their sustainability objectives. ${ }^{14}$

Sustainable development is thus increasingly important to lawyers. It is a growing part of law practice in nearly every practice area and involves many different skills. ${ }^{15}$ As the American Bar Association (ABA) Task Force on Sustainable Development concluded in 2014, the 'transition to sustainability in both governmental and private sector decision making is inevitable, and will profoundly affect the legal profession'. ${ }^{16}$ The transition towards sustainability in the legal profession is also reflected in and encouraged by a wide variety of activities in support of sustainability in law schools, which include courses, scholarship, facilities, and community service. ${ }^{17}$

More broadly, the definitional issue matters because it is now more than two decades - almost a human generation - since the 1992 UNCED, or Rio Earth Summit, first endorsed sustainable development and brought the concept to prominence. The historic understanding - that sustainable development is a form of development, and that integrated decision making for human well-being is at its core - has often been obscured, particularly for people who came of age after that time, or for those who are new to the concept. As is suggested in Part 3 below, the use of 'sustainability' as a shorthand for 'sustainable development' has contributed to the loss of that original meaning. The idea that sustainable development is a form of development has been replaced, to a significant degree, with a dictionary definition understanding of 'sustainable' - something that is 'able to be maintained or continued', ${ }^{18}$ or simply as something that is vaguely 'green'. The historical understanding of

13 M. Vandenbergh, 'Private Environmental Governance' (2013) 99(1) Cornell Law Review, pp. 129-99.

J. Dernbach, 'The Essential and Growing Role of Legal Education in Achieving Sustainability' (2011) 60(2) Journal of Legal Education, pp. 489-518, at 493-4.

15 ABA, Task Force on Sustainable Development, 'First-Year Report', 31 July 2014, p. 2, available at: http://acoel.org/file.axd?file $=2014 \% 2 \mathrm{~F} 9 \% 2 \mathrm{FABA}+\mathrm{SD}+$ TaskForceRpt+2014.pdf. According to the Task Force, '[s] ustainability is affecting, or will affect, tax law, insurance, banking, finance, real estate development, environmental and energy law, among other fields': ibid. See J. Dernbach, L.A. DeHihns III \& I.R. Feldman, 'The Growing Importance of Sustainability to Lawyers and the ABA', Trends (ABA Section of Environment, Energy, and Resources), July/Aug. 2013, available at: http://papers.ssrn.com/ sol3/papers.cfm?abstract_id=2316264. See also N. Cleveland, 'Sustainability Reporting: The Lawyer's Response', Business Law Today, 4 Jan. 2015, available at: http://www.americanbar.org/publications/ blt/2015/01/04_pike.html.

16 ABA Task Force, ibid., at p. 4.

17 Dernbach, n. 14 above, at pp. 501-18.

18 Cambridge Dictionaries Online, available at: http://dictionary.cambridge.org/us/dictionary/americanenglish/sustainable. 
sustainability has also been weakened by the growing prominence of climate change as an issue. Unlike the situation in 1992, there is now overwhelming scientific evidence that climate change is already occurring, that more severe changes are likely to come, and that adaptation is both necessary and urgent. ${ }^{19}$ Some simply see climate change as the more important issue, and believe we must focus on addressing and preparing for its impacts, even though sustainable development provides a solid and dependable decision-making framework through which to address these impacts.

To be sure, the definitional issue is not new to sustainability; questions about its meaning and implications have surrounded the concept from its beginning. ${ }^{20}$ One response is to assert that we should simply forge ahead with the task of achieving sustainability, and not quibble about definitions. Yet, words and ideas matter. We cannot move ahead on sustainability without some confidence that we are doing what we need to do. Informed criticism of particular projects or proposals, based on a historical and functional understanding of sustainability, is far more likely to contribute to sustainable outcomes than criticism based on a misunderstanding of the term. The concept does not answer all questions, and there are frequently several reasonable answers to the same question. Yet, it answers many questions, and we need robust discussion and debate about what a historical and functional understanding of sustainable development requires in specific contexts. When we discuss what sustainable development actually means, we are discussing the kind of world in which we want to live in the face of major environmental and social challenges, and the laws and legal institutions needed to make that happen.

\section{HISTORY OF AN IDEA: SUSTAINABLE DEVELOPMENT}

Sustainable development is a decision-making framework for achieving and maintaining human well-being, both in the present and into the future. It is premised on principles of basic equity - that each human being is entitled to a certain quality of life and that the minimum conditions for human quality of life should be maintained from generation to generation. Sustainable development confronts the related problems of widespread environmental degradation and extreme poverty, which present profound threats to human well-being for both the present and future generations.

Sustainable development is based on a powerful critique of conventional development, and the minimal role that environmental protection tends to play in decision making for conventional development. While conventional development brings economic and social benefits, it also damages the environment and people who depend on it, thus offsetting to a significant degree the benefits it creates. The damage from conventional development to both human beings and the environment compromises society's ability to provide minimal conditions for human quality of life. To correct this failing, the key action principle for sustainable development is

19 Intergovernmental Panel on Climate Change (IPPC), Climate Change 2013: The Physical Science Basis, Contribution of Working Group I to the Fifth Assessment Report of the Intergovernmental Panel on Climate Change (Cambridge University Press, 2013).

20 B. Brown et al., 'Global Sustainability: Toward Definition' (1987) 11(6) Environmental Management, pp. $713-9$. 
integrated decision making - the integration of development and environmental objectives and considerations (including environmental quality, social justice, and economic viability) in deliberations.

A handful of principles support the integrated decision-making process. Parties should not use the absence of scientific certainty as a reason for postponing costeffective measures to prevent environmental degradation (the precautionary approach). Generally, parties should be responsible for the damage they cause (the polluter-pays principle). The public needs to be informed and involved in the process of making decisions (public participation). Taken together, these principles provide a framework for decision making. The simplicity of the framework facilitates its employment by decision makers at every level: public and private; global, national, regional or local. The framework is also supple enough to apply to both old and new problems, as well as to new dimensions of existing problems.

The overall objective of this decision-making framework is ecologically sustainable human development. From a functional perspective, sustainable development will happen when (or if) extreme poverty and widespread environmental degradation cease to exist. Sustainable development would change the way in which individual development projects occur, eliminating adverse effects or reducing them to de minimis levels, and even creating positive environmental outcomes. The framework itself, however, does not come with specific environmental and social objectives; those should be determined on a case-by-case basis in light of the overall objective.

This relatively straightforward approach for decision making emerges from an extensive history; accordingly, sustainable development is best understood in terms of its history. The idea of sustainable development evolved to address specific problems, and is best understood as a response to those problems. At the same time, sustainable development does not offer a formula for decision making. Many reasonable interpretations of the framework are possible. The history of sustainable development is a history of identifying what works. It is a 'toolbox' stocked with proven tools. This suggests that approaches to 'sustainability' that are not grounded in the framework developed over the past decades are less likely to be effective in addressing widespread environmental degradation and extreme poverty.

\subsection{Origins}

The origins of sustainable development have been traced to 'ancient civilizations and traditional legal systems' from around the world. ${ }^{21}$ The concept also has origins in European land use and forestry laws, some of which date back to the Middle Ages. ${ }^{22}$ Environmental and conservation laws of the United States (US) and other countries

21 International Court of Justice (ICJ), Gabčikovo-Nagymaros Project (Hungary v. Slovakia), Judgment, 25 Sept. 1997, ICJ Reports (1997), p. 98 (Weeramantry, J., concurring). See also William McDonough Architects \& M. Braungart, The Hannover Principles: Design for Sustainability (William McDonough Architects, 1992), p. 50 ('Examples of sustainability are not hard to cull from the history of world cultures').

22 Bosselmann, n. 12 above, at pp. 11-22. 
also provide a point of departure for sustainable development. ${ }^{23}$ This is particularly true of the US National Environmental Policy Act of 1969 (NEPA), which declares that the 'continuing policy of the Federal Government' is to 'create and maintain conditions, under which humans and nature can exist in productive harmony, that permit fulfilling the social, economic and other requirements of present and future generations' - language that captures the essence of a term that was not yet coined. ${ }^{24}$ At about the same time, other thinkers, such as Edward Goldsmith and Robert Allen, were working out what it meant for a society to be sustainable, as the quotation at the beginning of this article indicates. ${ }^{25}$

The term 'sustainable development' emerged for the first time in 1980, in a report of a non-governmental organization (NGO), the International Union for the Conservation of Nature and Natural Resources (IUCN). ${ }^{26}$ The report, a conservation strategy for living resources, explicitly linked conservation and development through the term 'sustainable development'. ${ }^{27}$ One year later, Lester Brown at the Worldwatch Institute made sustainability a household phrase with his 1981 book, Building a Sustainable Society. ${ }^{28}$ Brown did not make an effort to define a sustainable society; rather, he emphasized the unsustainable use of resources in past and present societies. ${ }^{29} \mathrm{~A}$ sustainable society, by implication, was a society that would avoid demonstrably unsustainable behaviour. However, Brown understood that maintaining environmental quality and sustainable behaviour required addressing problems of social inequality both within nations ${ }^{30}$ and among nations. ${ }^{31}$ Sustainability soon developed depth as an analytical tool in response to short-term improvements in agricultural yield in the Third World. Applying the concept of sustainability to agriculture allowed policy makers and agronomists to argue for more ecologically and culturally sensitive approaches to agriculture than had been embraced initially as part of the 'green revolution'. ${ }^{32}$

In 1987, the World Commission on Environment and Development (WCED), a blue ribbon panel brought together by the UN General Assembly (UNGA), issued a landmark report on sustainable development. The Commission, chaired by the Norwegian Prime Minister at the time, Gro Harlem Brundtland, endorsed the concept of sustainable development and recommended both an international conference and a programme of action to foster sustainable development. ${ }^{33}$

23 National Research Council (NRC), Committee on Incorporating Sustainability in the US Environmental Protection Agency (EPA), Sustainability and the U.S. EPA (National Academies Press, 2011), pp. 15-9; Cordonier Segger \& Khalfan, n. 3 above, at pp. 15-9. 42 U.S.C. $\$ 4331$ (a) (2006) (emphasis added).

Goldsmith \& Allen, n. 1 above.

IUCN, World Conservation Strategy: Living Resource Conservation for Sustainable Development (IUCN, 1980), available at: https://portals.iucn.org/library/efiles/html/WCS-004/cover.html; Cordonier Segger \& Khalfan, n. 3 above, at p. 17.

IUCN, ibid.

L.R. Brown, Building a Sustainable Society (W.W. Norton \& Co., 1981).

Ibid., at pp. 1-9, 245-71.

Ibid., at pp. 271-5 ('Simpler Life-Styles among the Affluent').

Ibid., at pp. $275-87$.

G. Douglass (ed.), Agricultural Sustainability in a Changing World Order (Westview Press, 1984).

WCED, Our Common Future (Oxford University Press, 1987), pp. 43-65, 343. 
The report, Our Common Future, contains what is probably the most often cited definition of sustainable development: 'Development that meets the needs of the present without compromising the ability of future generations to meet their own needs'. ${ }^{34}$ The Brundtland Commission emphasized again and again the importance of an integrated decision-making process to take into account both economic development and environmental quality to further human welfare. ${ }^{35}$

The UNCED, or Earth Summit, was held in Rio de Janeiro (Brazil) in 1992 in response to the Brundtland Report. The Conference produced a plan of action for sustainable development ('Agenda 21') 36 and a set of principles to guide the effort (the Rio Declaration on Environment and Development), ${ }^{37}$ The Rio Declaration principles continue to play a significant role in guiding laws and policies for sustainable development. ${ }^{38}$ Significantly, the UN opened two treaties for signature at this Conference: the UN Framework Convention on Climate Change (UNFCCC), ${ }^{39}$ and the Convention on Biological Diversity (CBD). ${ }^{40}$ Both treaties employ sustainable development concepts and principles. As a basic principle the UNFCCC states that ' $[\mathrm{t}]$ he Parties have a right to, and should, promote sustainable development' (Article 3.4). The objectives of the CBD include 'the conservation of biological diversity, the sustainable use of its components and the fair and equitable sharing of the benefits arising out of the utilization of genetic resources' (Article 1). Echoing Our Common Future, the CBD defines 'sustainable use' as 'the use of components of biological diversity in a way and at a rate that does not lead to the long-term decline of biological diversity, thereby maintaining its potential to meet the needs and aspirations of present and future generations' (Article 2). This language, however, also invokes the distinct tradition of commercial sustained yield. ${ }^{41}$

Since that time, intergovernmental processes have fleshed out the meaning and application of sustainable development in at least two ways. The first is a series of international conferences and reviews of progress in achieving sustainable development. These occurred on the $5^{\text {th }},{ }^{42}$ the $10^{\text {th }},{ }^{43}$ and the $20^{\text {th }} 44$ anniversaries

34 Ibid., at p. 24.

35 Ibid., at pp. 37-41.

36 N. 8 above.

37 Adopted at UNCED, Rio de Janeiro (Brazil), 3-14 June 1992, UN Doc. A/CONF.151/26 (Vol. I), available at: http://www.un.org/documents/ga/conf151/aconf15126-1annex1.htm.

38 For a detailed explanation of each of the principles contained in the Rio Declaration, see J. Viñuales (ed.), The Rio Declaration on Environment and Development: A Commentary (Oxford University Press, 2015).

39 New York, NY (US), 9 May 1992, in force 21 Mar. 1994, available at: http://unfccc.int.

40 Rio de Janeiro (Brazil) 5 June 1992, in force 29 Dec. 1993, available at: http://cbd.int.

41 See text at nn. 185-93 below.

42 UNGA Res. S/19-2, UN Doc. A/RES/S-19/2 (19 Sept. 1997), available at: http://www.un.org/ documents/ga/res/spec/aress19-2.htm (adopting the 'Programme for the Further Implementation of Agenda 21', included in the Resolution).

43 UN World Summit on Sustainable Development (WSSD), Johannesburg (South Africa), 26 Aug. -4 Sept. 2002, 'Report of World Summit on Sustainable Development', UN Doc. A/CONF.199/20 (2002), available at: http://www.un.org/jsummit/html/documents/summit_docs/131302_wssd_report_ reissued.pdf (including 'Johannesburg Declaration on Sustainable Development' and 'Plan of Implementation of the World Summit on Sustainable Development').

44 'The Future We Want', UNGA Res. 66/288, UN GAOR, 66 th Sess., UN Doc. A/CONF.216/16 (11 Sept. 2012), available at: http://www.un.org/ga/search/view_doc.asp?symbol=A/RES/66/288\&Lang=E. 
of the Earth Summit. The most recent conference, Rio+20, not only renewed the Earth Summit commitments; it also created new processes to resolve a handful of major issues. These include the strengthening of international environmental institutions and the establishment of sustainable development goals. ${ }^{45}$

A second series of international processes involves the implementation of specific treaties that are intended to encourage sustainable development. These include the UNFCCC $^{46}$ and the CBD. ${ }^{47}$ The text of treaties that have been negotiated since 1992 reflects the sustainable development framework, although not always fully. ${ }^{48}$ The Preamble to the treaty creating the World Trade Organization (WTO) specifically recognizes 'the objective of sustainable development'. ${ }^{49}$ The Treaty on the European Union (TEU) declares sustainable development to be one of the EU's objectives, and the European Union (EU) has been implementing a sustainable development strategy since $2001 .^{50}$

\subsection{A Decision-Making Framework}

Because sustainable development is a framework for making decisions based on the integration of development and environmental objectives or considerations, it is important to understand what 'development' means in this context. North Americans tend to be uncomfortable with the term 'development'; they often associate it with the conversion of their favourite woodland or field into housing or a shopping mall. Yet, at the international level, where the term 'sustainable development' originated, development has a different meaning. As an international project, development came into prominence at the end of the Second World War when a series of international agreements and treaties created an architecture that supported and fostered it. Development includes not only economic development, but also social development and human rights, and it depends on peace and security. ${ }^{51}$ Social development and economic

45 J. Dernbach, 'The Unfinished Story of the Rio Plus 20 Conference' (2012) 35 Daily Environment Report (BNA) No. 980, pp. 1-6, available at: http://papers.ssrn.com/sol3/papers.cfm?abstract $\mathrm{id}=2169500$. As of the date of writing, the UN is scheduled to adopt sustainable development goals in Sept. 2015: see n. 10 above.

46 The parties to the UNFCCC (n. 39 above) have held annual conferences since 1995: see Documents of the Conference of the Parties (COP) at its First Session, available at: http://unfccc.int/cop5/resource/ cop1.html. At the 1997 COP in Kyoto (Japan), the parties agreed to a protocol to reduce GHG emissions by approx. 5\% below 1990 levels by 2008-12: Art. 3.1, Kyoto Protocol to the United Nations Framework Convention on Climate Change, Kyoto (Japan), 11 Dec. 1997, in force 16 Feb. 2005, available at: http://unfccc.int/kyoto_protocol/items/2830.php. A successor agreement to the Kyoto Protocol is expected at the COP in Paris (France) at the end of 2015.

47 N. 40 above; the CBD COP now meets every other year, and has developed two Protocols, available at: https://www.cbd.int/cop.

48 Cordonier Segger \& Khalfan, n. 3 above, at p. 95; P. Sands \& J. Peel, Principles of International Environmental Law, $3^{\text {rd }}$ edn (Cambridge University Press, 2012), pp. 187-236.

49 Marrakesh Agreement Establishing the WTO, Marrakesh (Morocco), 15 Apr. 1994, in force 1 Jan. 1995, available at: http://www.wto.org/english/docs_e/legal_e/24-scm_01_e.htm. See M. Gehring \& M. Cordonier Segger (eds), Sustainable Development in World Trade Law (Kluwer Law International, 2005).

50 Arts. 3(3), 3(5), 21(2)(d), 21(2)(f) and 11, Treaty on the Functioning of the European Union (TFEU), Lisbon (Portugal), 13 Dec. 1997, in force 1 Dec. 2009, available at: http://europe.eu/lisbon_treaty/ full_text.

51 J. Dernbach, 'Sustainable Development as a Framework for National Governance' (1998) 49(1) Case Western Reserve Law Review, pp. 1-103. 
development are mutually dependent. Children who are poorly educated or who are not healthy are unlikely to grow up to be productive or effective workers. Economic development, in turn, enables higher levels of education and public health. ${ }^{52}$

Economic and social development work together to improve human freedom, opportunity and quality of life. As the Brundtland Commission states, '[ $t$ ]he satisfaction of human needs and aspirations is the major objective of development'. ${ }^{53}$ Economist Amartya Sen explains development as a process that enlarges individual freedom. ${ }^{54}$ International law specialist Rumu Sarkar writes: 'For most practitioners and theorists ... the overall objectives of alleviating poverty and human suffering and of improving the human condition more generally are the desired end product of the development process'. 55

This model has been successful in many ways. It has helped to prevent a third world war, ${ }^{56}$ it has fostered economic growth, and it has improved living conditions. ${ }^{57}$ However, this model, and the post-war international agreements that support it, say little or nothing about natural resources or environmental protection. The Brundtland Commission found that development had contributed to two problems - widespread environmental degradation, and poverty - which not only threaten to undermine the achievements of development; they also mean that development is not fully effective on its own terms. ${ }^{58}$

As the Brundtland Commission explained, poverty and environmental degradation reinforce each other. ${ }^{59}$ People in poverty tend to engage in environmentally destructive activities such as deforestation, and farming or grazing on degraded lands. They often have no other choice in order to survive. Yet, unhealthy and unsafe conditions from environmental degradation keep these people in poverty. There is ample evidence of the adverse effects of environmental degradation on human wellbeing in both developed and developing countries. ${ }^{60}$ An example of how conventional development often benefits some at the expense of others, and how law supports that result, can be seen in Sipriano v. Great Spring Waters of America, Inc. ${ }^{61}$ where a bottled water company used so much of a groundwater aquifer for its operation that its neighbours were deprived of water for their own use. The Texas

52 Ibid., at pp. 9-14.

53 WCED, n. 33 above, at p. 54.

54 A. Sen, Development as Freedom (Knopf, 1999); see also K. De Feyter, World Development Law: Sharing Responsibility for Development (Intersentia, 2001), p. 32.

55 R. Sarkar, International Development Law: Rule of Law, Human Rights, and Global Finance (Oxford University Press, 2009), p. xvi.

56 M. Mandelbaum, The Ideas that Conquered the World: Peace, Democracy, and Free Markets in the Twenty-first Century (Public Affairs, 2002).

57 UN Environment Programme (UNEP), Keeping Track of Our Changing Environment: From Rio to Rio+20 (UNEP, 2011).

58 WCED, n. 33 above, at pp. 28-37.

59 Ibid.

60 J. Dernbach, P. Salkin \& D. Brown, 'Sustainability as a Means of Improving Environmental Justice' (2012) 19(1) Missouri Journal of Environmental and Sustainability Law, pp. 1-34; see also Y. Le Bouthillier et al. (eds), Poverty Alleviation and Environmental Law (IUCN Academy of Environmental Law, 2012).

61 S.W.3d 75 (Tex. 1999). 
Supreme Court upheld a grant of summary judgment against the neighbours, holding that the common law rule of capture protected the company from liability. In a concurring opinion, Justice Hecht wrote: 'In the last several decades it has become clear, if it was not before, that it is not regulation that threatens progress, but the lack of it' ${ }^{62}$ Put plainly, unsustainable development is also unjust development and unjust development is generally unsustainable.

While hundreds of scholars and policy makers have quoted the definition of sustainable development from Our Common Future, fewer recognize the essential accomplishment of that report: linking environmental quality with meeting the needs of the world's poor through the functioning of the world economy. As the Brundtland Commission explained:

Environment and development are not separate challenges; they are inextricably linked. Development cannot subsist upon a deteriorating environmental resource base; the environment cannot be protected when growth leaves out of account the costs of environmental destruction. These problems cannot be treated separately by fragmented institutions and policies. They are linked in a complex system of cause and effect. ${ }^{63}$

Sustainable development would correct but not replace the existing international development model. The basic idea is to ensure that development is also environmentally protective or restorative. Development's goals of human freedom, opportunity, and quality of life remain; sustainable development, Amartya Sen writes, can preserve and extend individual freedom for both the present and future generations. ${ }^{64}$ Principle 1 of the Rio Declaration ${ }^{65}$ states: 'Human beings are at the centre of concerns for sustainable development'. However, there is a twist: 'They are entitled to a healthy and productive life in harmony with nature ${ }^{,}{ }^{6}$

Equity, including intergenerational equity, provides the context in which sustainable development is supposed to occur. According to Rio Declaration Principle 3, ' $[\mathrm{t}]$ he right to development must be fulfilled so as to equitably meet developmental and environmental needs of present and future generations'. As Edith Brown Weiss explained, each generation is entitled to a quality of planet enjoyed by prior generations, and also has an obligation to pass to the next generation a quality of planet that is no worse than it has received. ${ }^{67}$ Because poverty and environmental degradation are linked,

62 Ibid., at p. 82.

63 WCED, n. 33 above, at p. 48. Similarly, the IUCN Conservation Strategy (n. 26 above, Executive Summary, para. 3) describes 6 'main obstacles to achieving conservation', nearly all of which are based on or linked with 'failure to integrate conservation and development'.

64 A. Sen, The Idea of Justice (Belknap Press, 2009), pp. 248-52.

65 N. 37 above.

66 Ibid. (emphasis added). The IUCN (n. 26 above, at Ch. 1, para. 12) states that 'the goal of the World Conservation Strategy is the integration of conservation and development to ensure that modifications to the planet do indeed secure the survival and well-being of all people'.

67 E. Brown Weiss, 'In Fairness to Future Generations and Sustainable Development' (1992) 8(19) American University International Law Review, pp. 19-26, at 22-3. She also argues that each generation should conserve the options of future generations by conserving 'the diversity of the natural and cultural resource base', and that all people in the current generation should have the same minimal level of access to this legacy: ibid., at pp. 22-3. See also E. Brown Weiss, In Fairness to Future Generations: International Law, Common Patrimony, and Intergenerational Equity (Transnational, 1989). 
equity within the current generation is necessary for equity between generations. Intergenerational equity is reflected in both the UNFCCC $^{68}$ and the CBD. ${ }^{69}$

The foundational action principle of sustainable development is integrated decision making. ${ }^{70}$ 'In order to achieve sustainable development', Rio Declaration Principle 4 states, 'environmental protection shall constitute an integral part of the development process and cannot be considered in isolation from it'. ${ }^{71}$ The IUCN World Conservation Strategy states that the 'most effective way' to avoid ecological damage caused by development 'is to integrate every stage of the conservation and development processes, from the initial setting of policies to their eventual implementation and operation'. ${ }^{72}$ Similarly, Our Common Future states: 'The common theme throughout this strategy for sustainable development is the need to integrate economic and ecological considerations in decision making. They are, after all, integrated in the workings of the real world'. ${ }^{73}$ Integrated decision making, the Brundtland Commission said, is the 'chief institutional challenge' of the time: 'The ability to choose policy paths that are sustainable requires that the ecological dimensions of policy be considered at the same time as the economic, trade, energy, agricultural, industrial, and other dimensions - on the same agendas and in the same national and international institutions' ${ }^{74}$ The central role of integrated decision making is repeatedly stated in 'Agenda $21,{ }^{75}$ the UNFCCC, ${ }^{76}$ and the CBD. ${ }^{77}$ Integrated decision making not only recognizes a broader range of considerations than 'business as usual', but also allows for a broader range of solutions. ${ }^{78}$

Significantly, there are different kinds of integration. ${ }^{79}$ Procedural integration occurs when environmental and social effects are considered as part of the decisionmaking process. This is very much like the environmental assessment process required by NEPA in the US, which requires federal agencies to assess the environmental effect of, and alternatives to, major federal projects that may have significant

68 Art. 3(1) UNFCCC: 'The Parties should protect the climate system for the benefit of present and future generations of humankind, on the basis of equity and in accordance with their common but differentiated responsibilities and respective capabilities'. The parties also state that they are ' $[d]$ etermined to protect the climate system for present and future generations': Preamble UNFCCC (emphasis added).

69 The CBD includes both conservation and sustainable use among its objectives, and defines sustainable use as use of biological material in a way 'that maintains its potential to meet the needs and aspirations of present and future generations' (Arts 1 and 2 CBD). The Preamble states that the parties are '[d]etermined to conserve and sustainably use biological diversity for the benefit of present and future generations' (emphasis added).

70 J. Dernbach, 'Achieving Sustainable Development: The Centrality and Multiple Facets of Integrated Decisionmaking' (2003) 10 Indiana Journal of Global Legal Studies, pp. 247-85; see also Cordonier Segger \& Khalfan, n. 3 above, at p. 103,

71 See also Principle 25 ('Peace, development and environmental protection are interdependent and indivisible').

72 IUCN, n. 26 above, at Ch. 9, para. 1.

73 WCED, n. 33 above, at p. 71.

74 Ibid., at p. 313.

75 UNCED, 'Agenda 21', n. 8 above, at paras 8.4 and 8.16.

76 Arts 3(4) and 4(1)(f) UNFCCC.

77 Arts 10(a) and 6(b) CBD.

78 Dernbach, n. 70 above, at pp. 281-4.

79 For a detailed explanation, see Dernbach, ibid., at pp. 260-5. 
environmental impacts. ${ }^{80}$ Substantive integration requires more than consideration of environmental and social effects; it requires the establishment and realization of specific and substantive environmental and social goals as part of the decision-making process. Under NEPA, an agency may give full consideration to environmental and social effects and still proceed with a damaging project. ${ }^{81}$ As a general matter, that is not how substantive integration works. Moreover, substantive integration is far more likely to further sustainable development than is procedural integration.

A handful of other principles support and guide integrated decision making. ${ }^{82}$ These include the 'precautionary approach'. As stated in Rio Declaration Principle 15: 'Where there are threats of serious or irreversible damage, lack of full scientific certainty shall not be used as a reason for postponing cost-effective measures to prevent environmental degradation'. The precautionary approach is about the level of scientific support required for the environmental aspect of integrated decision making. ${ }^{83}$ The UNFCCC includes a near identical formulation of the precautionary approach with regard to the goal of minimizing the causes of climate change and mitigating its adverse effects. ${ }^{84}$ The precautionary approach also guides implementation of the CBD. ${ }^{85}$

The polluter-pays principle is also supposed to guide integrated decision making. Rio Declaration Principle 16 states: 'National authorities should endeavor to promote the internalization of environmental costs and the use of economic instruments, taking into account the approach that the polluter should, in principle, bear the cost of pollution, with due regard to the public interest and without distorting international trade and investment'. Internalization of costs means their incorporation into the price of a product or service. This price guides decision making by integrating information about economic and environmental costs. ${ }^{86}$ This is basic environmental economics, but the polluter-pays principle also contains more than a grain of social justice. What economists refer to as externalities are the adverse effects of a conventional development project or activity on other people and the environment on which they depend.

Public participation, access to information and justice are also needed to foster integrated decision making, according to Rio Declaration Principle 10. Among other things, they can ensure more informed and more responsible decision making by

8042 U.S.C. $\$$ 4332. Approximately 160 countries have similar laws: R. Lazarus, 'The National Environmental Policy Act in the U.S. Supreme Court: A Reappraisal and a Peek Behind the Curtains' (2012) 100 Georgetown Law Journal, pp. 1507-86, at 1510.

81 Robertson v. Methow Valley Citizens Council, 490 U.S. 332, 350-2 (1989).

82 Dernbach, n. 70 above, at pp. 253-8. The principles discussed in the text are illustrative but not exhaustive. Another is Rio Declaration Principle 8: 'To achieve sustainable development and a higher quality of life for all people, States should reduce and eliminate unsustainable patterns of production and consumption and promote appropriate demographic policies'. See also 'Summary of Proposed Legal Principles for Environmental Protection and Sustainable Development Adopted by the WCED Experts Group on Environmental Law', in WCED, n. 33 above, at pp. 348-51.

83 Dernbach, n. 70 above, at pp. 254-5; see also Cordonier Segger \& Khalfan, n. 3 above, at pp. 143-55 (explaining the history and application of the precautionary approach).

84 Art. 3(3) UNFCCC.

85 See, e.g., R. Cooney \& B. Dickson (eds), Biodiversity and the Precautionary Principle: Risk, Uncertainty and Practice in Conservation and Sustainable Use (Routledge, 2005).

86 Dernbach, n. 70 above, at p. 254. 
governmental and non-governmental bodies. ${ }^{87}$ At a practical level, integrated decision making is more likely to occur when people representing a variety of social, environmental and economic perspectives participate effectively in the decisions that affect them, and have access to accurate information that is relevant to those decisions. Recourse to the courts enhances the likelihood that public and private decision makers will take them seriously, and provides an opportunity to correct or reverse incorrect decisions. These principles, taken together, provide the decision-making framework for sustainable development.

\subsection{Environmental and Social Goals}

A striking feature of the sustainable development framework is the absence of a single or specific environmental or social goal towards which integrated decision making should be directed. ${ }^{88}$ The Brundtland Commission's iconic definition of sustainable development -'development that meets the needs of the present without compromising the ability of future generations to meet their own needs ${ }^{89}$ - says nothing about the environment, let alone an environmental goal. Still, it is possible to discern an overall approach to environmental and social goals.

Firstly, the sustainable development framework is a response to deteriorating environmental conditions around the world and widespread global poverty. These undermine and interfere with human well-being. It follows that the minimum aggregate environmental goal of sustainable development is to reduce degradation to a level that does not interfere with human well-being, and that the minimum aggregate social goal is to eliminate widespread extreme poverty. Significantly, these minimum aggregate goals can accommodate new information and ideas. For example, the concept of 'planetary boundaries', articulated in 2009, provides a way of understanding the space within which humans can operate safely. Scientific evidence indicates that several of these boundaries have already been crossed..$^{90}$ It thus makes sense to conclude that sustainable development requires actions that keep humans within (and return humans to) those boundaries. The objective of the UNFCCC also captures this idea of a minimum goal: 'stabilization of greenhouse gas concentrations in the atmosphere at a level that would prevent dangerous anthropogenic interference with the climate system' (Article 2). The Convention could conceivably have established a goal of returning the atmosphere to greenhouse gas (GHG) concentrations that existed at the dawn of the

87 Ibid., at pp. 255-6; Cordonier Segger \& Khalfan, n. 3 above, at pp. 156-66; J. Dernbach, 'Citizen Suits and Sustainability' (2004) 10 Widener Law Review, pp. 503-26. Parties to the UNFCCC have agreed to '[p]romote and facilitate' both 'public access to information on climate change and its effects' and 'public participation in addressing climate change and its effects': Art. 6(a)(ii)-(iii) UNFCCC.

88 Bosselmann, n. 12 above, at pp. 22-5. It is similarly difficult to find a single specific social goal beyond the satisfaction of human needs.

89 Ibid., at p. 24.

90 J. Rockström et al., 'Planetary Boundaries: Exploring the Safe Operating Space for Humanity' (2009) 14(2) Ecology and Society 32, available at: http://www.ecologyandsociety.org/vol14/iss2/art32. See also R. Kim \& K. Bosselmann, 'International Environmental Law in the Anthropocene: Towards a Purposive System of Multilateral Environmental Agreements' (2013) 2(2) Transnational Environmental Law, pp. 285-309 (arguing that protection of the integrity of Earth's life-support system should be considered as the overall goal for international environmental law). 
industrial revolution, but it did not. The COP to the UNFCCC, moreover, has translated that objective as 'a likely chance of holding the increase in global average temperature below $2^{\circ} \mathrm{C}$ or $1.5^{\circ} \mathrm{C}$ above pre-industrial levels'. ${ }^{91}$ Put bluntly, the UNFCCC's objective is damage control. This objective, moreover, is reflected in the fact that the UNFCCC, in Article 4.1(b), specifies measures that parties are to undertake to both mitigate climate change and adapt to climate change. Even in 1992, when the effects of human-induced climate change were much less obvious than they are now, the UNFCCC anticipated that parties would need to adapt to a changing climate at the same time as they reduced their GHG emissions.

The CBD takes a similar approach. According to Article 1, the objectives of the $\mathrm{CBD}$ are 'the conservation of biological diversity, the sustainable use of its components and the fair and equitable sharing of the benefits arising out of the utilization of genetic resources ...'. In 2002, concerned that the 'rate of biodiversity loss is increasing at an unprecedented rate, threatening the very existence of life as it is currently understood', the CBD COP adopted a strategic plan based on a goal of damage control. ${ }^{92}$ To secure 'a more effective and coherent implementation of the three objectives of the Convention', they agreed 'to achieve by 2010 a significant reduction of the current rate of biodiversity loss at the global, regional and national level'. 93 Then, in 2010, finding that the '2010 biodiversity target has not been achieved' in spite of some progress, the CBD COP adopted a set of 20 more precise goals, most of which are to be met by $2020 .{ }^{94}$ The environmental aspects of these more precise goals are a mix of damage control and sustainable use. ${ }^{95}$

Secondly, the linkage between environmental quality and resource availability, on the one hand, and human well-being, on the other, suggests that environmental protection improves human quality of life. This indicates the value and importance of reversing negative trends beyond the minimum necessary to support and maintain human life. Such an objective may not be achievable in all cases, but it is reasonable and appropriate to conclude that ecological restoration, improved environmental quality and improved access to resources should be achieved wherever and whenever possible. That, after all, would foster and improve human quality of life - the ultimate objective of sustainable development.

Thirdly, a key premise of sustainable development is that governmental, business and non-governmental decision makers will establish appropriate environmental and

91 See, e.g., Decision 1/CP.17, 'Establishment of an Ad Hoc Working Group on the Durban Platform for Enhanced Action', in COP-17 Report, Durban (South Africa), 28 Nov.-11 Dec. 2011, Addendum, Part Two, UN Doc. FCCC/CP/2011/9/Add.1 (15 Mar. 2012), available at: http://unfccc.int/resource/docs/ 2011/cop17/eng/09a01.pdf.

92 'Strategic Plan for the Convention on Biological Diversity', COP-6 Decision VI/26 (2002), available at: http://www.cbd.int/decision/cop/?id=7200.

93 Ibid.

94 'Strategic Plan for Biodiversity 2011-2020', COP-10 Decision X/2 (2010), available at: http://www.cbd.int/decision/cop/?id=12268.

95 Compare, e.g., Target 5 ('By 2020, the rate of loss of all natural habitats, including forests, is at least halved and where feasible brought close to zero, and degradation and fragmentation is significantly reduced') with Target 7 ('By 2020 areas under agriculture, aquaculture and forestry are managed sustainably, ensuring conservation of biodiversity'): ibid. 
social goals in the specific context of the decisions that they are making. ${ }^{96}$ No one goal or set of goals will be appropriate in all contexts. The international sustainability texts refer to different goals; some things should be reduced, others increased, a few simply sustained. Moreover, the goals themselves are quite general, with few quantitative aims or timetables; the specific direction and timing of achievement of any sustainability initiatives are thus left to the public and private decision makers who choose to take these initiatives. When data and other information are unclear or conflicting, equity and the precautionary approach - two key principles in sustainable development - suggest erring on the side of human well-being and environmental protection. While the sustainable development framework provides some overall principles or guidance for setting goals, then, it does not contain a specific overall environmental or social goal. Sustainable Development Goals, which have been proposed but not finalized at the time of this writing, are likely to provide a more specific expression of the basic ideas expressed above.

\subsection{An Increasingly Used Framework}

The central conceptual achievement of sustainable development is to offer an alternative to the binary 'environment or development' narratives that have traditionally dominated public and private political discourse. There are those who prefer the environment to development, and those who prefer development to the environment. In this scheme, both sides are usually willing to make minor concessions to the other so long as their single and primary objective is substantially unaffected. However, there had been precious little space for those who seriously sought to advance both at the same time. By creating a space for new approaches to development based on equity that produce both environmental and non-environmental benefits, sustainable development provides a way for public and private decision makers in all countries to get past the apparent conflict between development and environment.

The ubiquity of the terms 'sustainability' and 'sustainable development', in a sweeping range of areas of human endeavour, the explosion in their use since 1987, and the creativity they have unleashed, suggest the power of opening up that space. Sustainability inspires us to change our way of life and develop new solutions to problems that are intractable if the only solutions are development or the environment, but not both.

Four reviews of sustainability activity in the US, published roughly every five years since the 1992 Rio Earth Summit, track the real but limited progress made to date. The first review, in 1997, conducted by one of the authors and students in his seminar, found little progress. ${ }^{97}$ The 2002 review, Stumbling Toward Sustainability, ${ }^{98}$

96 See, e.g., UNCED, 'Agenda 21', n. 8 above, at para. 8.3 (stating that 'the overall objective is to improve or restructure the decision-making process so that consideration of socio-economic and environmental issues is fully integrated ...' and ' $[\mathrm{w}] \mathrm{ith}$ the understanding that countries will develop their own priorities in accordance with their prevailing conditions, needs, national plans, policies, and programs ...').

97 J. Dernbach \& Widener University Law School Seminar on Law and Sustainability, 'U.S. Adherence to Its Agenda 21 Commitments: A Five-Year Review' (1997) 27 Environmental Law Reporter, pp. 10504-25.

98 N. 3 above. 
was edited by one of the authors and written by more than three dozen experts, representing a wide range of perspectives and disciplines from universities, NGOs, and the private sector, who assessed progress over a wide range of topics. They concluded that in 'virtually every area of American life, a few people and organizations are exercising leadership for sustainability'. ${ }^{99}$ The next two reviews were books to which both authors of this article contributed. The 2009 review, Agenda for a Sustainable America, based on essentially the same set of contributors, found that the US 'has made significant progress since 2002 in at least six areas: local governance, brownfields redevelopment, business and industry, higher education, kindergarten through $12^{\text {th }}$ grade education, and religious organizations'. ${ }^{100}$ The most recent review, published in 2012 and entitled Acting as if Tomorrow Matters: Accelerating the Transition to Sustainability, is based on contributions from 51 experts in a wide variety of fields. It found that while 'the United States has made some progress in the two decades since the Earth Summit', the 'sustainability destination is now farther away than it was in 1992', largely because of the growing challenge of climate change. ${ }^{101}$ The review continues:

Yet there is nonetheless an emerging sustainability movement in the United States. It includes dedicated practitioners in a wide variety of fields who have thought deeply about what sustainability means in different contexts and why it is attractive, and whose day-to-day job is to make it happen, fix what doesn't work, and improve results. They are engaged in a wide variety of fields, including agriculture, energy, manufacturing, technology, community planning and development, business and industry, government, education, building construction, engineering, and law. ${ }^{102}$

Sustainability activities are now occurring in the public sector in the US at the local, state, federal, and tribal levels. They also happen in virtually every area of business activity and on a wide range of issues, including but not limited to education, water, oceans and estuaries, biodiversity conservation, forestry, toxic chemicals, hazardous waste, municipal solid waste, transportation, and international trade. By spring 2015, for example, 691 presidents and chancellors of American and Canadian universities had signed the American College and University Presidents' Climate Commitment, pledging to take 'actions to make climate neutrality and sustainability a part of the curriculum and other educational experience for all students'. ${ }^{103}$ Many countries are making at least some effort to move in a more sustainable direction. ${ }^{104}$

99 J. Dernbach, 'Synthesis', in Dernbach, ibid., at p. 2.

100 J. Dernbach \& F. Cheever, 'Progress Toward Sustainability: A Report Card', in Dernbach, Agenda for a Sustainable America, n. 3 above, at pp. 15-6.

101 Dernbach et al., Acting as if Tomorrow Matters, n. 3 above, at p. 9.

102 Ibid., at pp. 9-10. There is also abundant evidence of a global movement for sustainable development; Hawken estimates that more than a million NGOs around the world are 'working toward ecological sustainability and social justice': P. Hawken, Blessed Unrest: How the Largest Movement in the World Came into Being and Why No One Saw It Coming (Viking, 2007), p. 2.

103 American College \& University Presidents' Climate Commitment, 'Text of the American College \& University Presidents' Climate Commitment', available at: http://www.presidentsclimatecommitment. org/about/commitment. Of these, 533 signatories had submitted climate action plans.

104 UN Conference on Sustainable Development, n. 9 above, at para. 19. See also A. Ross, Sustainable Development Law in the UK: From Rhetoric to Reality? (Routledge, 2011). 
The integrated decision-making process required by sustainability shapes a variety of specific practices in every economic sector, at every level of government, and in a wide variety of NGOs. These practices cover private certificate and labelling programmes for green building, sustainable forestry, and energy savings. ${ }^{105}$ They also include voluntary reporting and auditing standards, including the Sustainability Reporting Guidelines issued by the Global Reporting Initiative, which have emerged as the standard for corporate sustainability reporting. ${ }^{106}$ Hundreds of major corporations have established sustainability policies and sustainability offices. ${ }^{107}$ They have developed and are implementing strategies to achieve specific sustainability objectives, such as reducing water use or GHG emissions by a specific amount by a particular date. They work cooperatively to improve the communities in which they operate and publicly report on their sustainability activities. In so doing, they reduce costs and improve their profitability. ${ }^{108}$

Best practices for sustainability are being developed and continuously refined and improved in a variety of other fields, such as higher education, chemical manufacturing, and the practice of law. ${ }^{109}$ Better tools for integrating social, economic, and environmental information for decision making are being more broadly applied, including accounting for ecosystem services, industrial ecology, and environmental management systems. ${ }^{110}$

Sustainable development has also influenced the development and implementation of law in a variety of ways. Many US state and federal laws foster GHG reductions; renewable energy; energy efficiency and conservation in buildings, transportation, and industry; and distributed energy. ${ }^{111}$ Sustainable development ideas also frame laws in a wide range of other contexts, including brownfields redevelopment, ${ }^{112}$ smart growth, ${ }^{113}$ public access to information, ${ }^{114}$ recycling, ${ }^{115}$ biodiversity conservation, ${ }^{116}$ and green building. ${ }^{117}$ Indeed, the US Environmental Protection Agency (EPA)

105 Dernbach, Acting as if Tomorrow Matters, n. 3 above, at pp. 156-9.

106 Ibid., at pp. 159-60.

107 See, e.g., J. Smith, 'The World's Most Sustainable Companies of 2014', Forbes Magazine, 22 Jan. 2014, available at: http://tinyurl.com/forbes-sust.

108 A. Savitz \& K. Weber, The Triple Bottom Line (Jossey-Bass, 2013).

109 Dernbach, Acting as if Tomorrow Matters, n. 3 above, at pp. 160-1.

110 Ibid., at pp. 167-72.

111 Ibid., at pp. 34-5; S. Ferrey, 'Solving the Multimillion Dollar Constitutional Puzzle Surrounding State “Sustainable” Energy Policy' (2014) 49(1) Wake Forest Law Review, pp. 121-85, at 122 (describing net metering, renewable portfolio standards, renewable system benefit charges, carbon/GHG regulation, and feed-in tariffs as 'the primary pillars of sustainable energy policy' in the US).

112 J. Eisen, 'Brownfields Development: From Individual Sites to Smart Growth', in Dernbach, Agenda for a Sustainable America, n. 3 above, pp. 57-69.

113 P. Salkin, 'Land Use: Blending Smart Growth with Social Equity and Climate Change Mitigation', in Dernbach, ibid., pp. 349-63.

114 C. Bruch, F. Irwin \& G. Bass, 'Public Access to Information, Participation, and Justice: Forward and Backward Steps Toward an Informed and Engaged Citizenry', in Dernbach, ibid., pp. 459-78.

115 M. Chertow, 'Municipal Solid Waste: Building Stronger Connections to Jobs and the Economy', in Dernbach, ibid., at pp. 335-45.

116 D. Tarlock \& A. Zabel, 'Biodiversity Conservation: An Unrealized Aspiration', in Dernbach, ibid., pp. 269-84.

117 S. Kaplow, 'Can Green Building Law Save the Planet?' (2014) 3 University of Baltimore Journal of Land and Development, pp. 131-79. 
increasingly integrates sustainability into the implementation of the laws it administers. $^{118}$ In 2001, the Oregon legislature established sustainability as state policy and created administrative mechanisms and specific goals to implement that policy. ${ }^{119}$ The Oregon statute is one of hundreds of references to sustainability in federal and state statutes in the US alone. ${ }^{120}$

Two key factors drive these activities. Firstly, sustainable development generally produces greater net benefits than does conventional development. The framework can generate a combination of economic, social, and environmental benefits instead of just one type, which may come at the cost of others. ${ }^{121}$ Thus, sustainable development is likely to produce greater net benefits, and fewer costs, than conventional development. In fact, much environmental protection has been accomplished in recent years by laws that also foster economic development. ${ }^{122}$ These more positive outcomes also include improved quality of life, cost savings, human health, environmental protection, and corporate profitability. ${ }^{123}$

Secondly, actors who fail to employ an integrated sustainability-based decisionmaking approach confront the growing costs and challenges of 'business as usual', particularly in the face of climate change. ${ }^{124}$ As 'the demands of environmental protection, social improvement and economic development become increasingly intertwined', designers of laws and policies are drawn to using this framework, whether they intend to foster sustainable development or not. ${ }^{125}$ These two drivers are likely to become even more important in the years ahead, as practices are improved and as population and economic growth impose greater pressures on environmental quality and resource availability.

Despite this change, progress over the last two decades has been disappointing. A consensus for faster progress was expressed at the 2012 UN Conference on Sustainable Development (Rio+20). The final outcome document for the conference, The Future We Want, emphasizes the need to 'accelerate progress' towards sustainability. ${ }^{126}$ Similarly, in 2012 the UNFCCC COP-18 agreed on the importance

118 US EPA, 'Fiscal Year 2014-2018 EPA Strategic Plan', 10 Apr. 2014, available at: http://www2.epa. gov/sites/production/files/2014-09/documents/epa_strategic_plan_fy14-18.pdf (identifying 'cleaning up communities and advancing sustainable development' as one of the EPA's five goals and 'working toward a sustainable future' as one of four cross-agency strategies); NRC, Committee on Incorporating Sustainability in the US EPA, Sustainability and the U.S. EPA (National Academies Press, 2011).

119 Ore. Rev. Stat. $\mathbb{S}$ 184.421-3.

120 See, e.g., California Water Code $\$ 10727$ (development and implementation of groundwater sus-

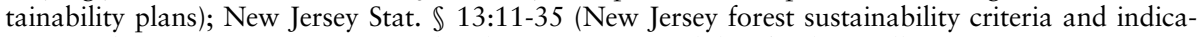

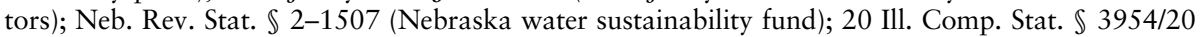
(Illinois Green Governments Coordinating Counsel sustainability goals).

121 Dernbach, Acting as if Tomorrow Matters, n. 3 above, at pp. 287-92.

122 J. Dernbach, 'Creating the Law of Environmentally Sustainable Economic Development' (2011) 28(3) Pace Environmental Law Review, pp. 614-41.

123 Dernbach, Acting as if Tomorrow Matters, n. 3 above, at pp. 161-5.

124 Ibid., at pp. 165-7.

125 Cordonier Segger \& Khalfan, n. 3 above, at p. 226. See also E. Goode, 'Farmers Put Down the Plow for More Productive Soil', The New York Times, 9 Mar. 2015, available at: http://tinyurl.com/goode-nyt.

126 N. 9 above, at para. 18. 
of 'accelerating the reduction of global greenhouse gases', and to give greater attention to climate change adaptation. ${ }^{127}$

\section{UNDERSTANDING, ANSWERING, AND LEARNING FROM 'THE DISCONTENTS'}

There are three main lines of criticism against sustainable development and sustainability. One is that the terms are too boring to garner the kind of public enthusiasm required to motivate change. Another is that the terms are too vague to be taken seriously. The final line of criticism addressed here is that, in light of the seriousness of accelerating climate disruption, sustainability is simply too late to be effective. These are not the only criticisms, to be sure, but they are the most prominent and serious. ${ }^{128}$ Each contains core truths that deserve to be taken seriously. However, we argue that each can be reconciled with the framework described in Part 2, and none of them provide an effective alternative to that framework.

What can we learn from the critics? Most obviously, definitions matter. It is essential to articulate what advocates and critics respectively mean by 'sustainability' and 'sustainable development', as this increases the likelihood that advocates and critics will better understand each other. The analysis below shows that some categorical-sounding criticisms of sustainability are made by people who mostly agree with the framework.

In addition, we should distinguish between two kinds of criticism. On the one hand are critics who are hostile to sustainable development; who would replace the concept with something else, such as resilience; or who are simply sceptical about any possibility of successfully addressing widespread environmental degradation and extreme poverty. On the other hand are those whose criticisms (constructive or otherwise) could be used to improve the manner in which sustainability projects or proposals are implemented or applied. In this second category are people who are sympathetic to sustainability but believe that the concept has become amorphous and subject to misuse or manipulation. Here, too, definitions matter.

Moreover, the critics collectively raise a challenging question about how to calibrate the sustainability message. Sustainable development is not simply a framework for avoiding or minimizing daunting challenges; it also provides opportunities and may lead to a higher quality of human life. Some critics say sustainable development is too optimistic; others say that it is too pessimistic; it is probably best to explain both possibilities.

Finally, the critics make points that could be used to improve the manner in which sustainable development projects and proposals are designed and implemented. Given the challenges confronting human society, we should take good ideas from wherever they come.

127 Decision 2/CP.18, 'Advancing the Durban Platform', in COP-18 Report, Doha (Qatar), 26 Nov. -8 Dec. 2012, Addendum, Part Two, UN Doc. FCCC/CP/2012/8/Add.1 (28 Feb. 2013), available at: http://unfccc.int/resource/docs/2012/cop18/eng/08a01.pdf.

128 For a discussion of another and, in the authors' view, less credible challenge to sustainability, see J. Dernbach, 'Facing Down the So-Called Agenda 21 "Conspiracy": Lessons for Planners' (2015) Planning, pp. 20-5. 


\subsection{Too Boring}

For some, the term 'sustainability' expresses an idea that is too modest or unappealing. They prefer to focus on something more positive, such as 'abundance' or 'thriveability'. ${ }^{129}$ While these goals are attractive, they are not alternatives to sustainability. Rather, they are goals that could be, and should be, considered and applied in sustainable development decisions. They are also consistent with and necessary for the furtherance of the ultimate objectives of sustainable development: human freedom, opportunity, and quality of life. This perspective can add value to dialogue about sustainable development when it encourages or prods decision makers to adopt more ambitious environmental and social goals.

Of course, it is easy to imagine more exciting phrases than 'sustainable development'. After four decades, the concept lacks novelty. Nicola Lugaresi, summarizing decades of international conferences, writes of the 'unbearable tiredness of sustainable development'. ${ }^{130}$

'How exciting is sustainability?', architect William McDonough and chemist Michael Braungart ask in their 2002 book, Cradle to Cradle: Remaking the Way We Make Things. ${ }^{131}$ 'If a man characterized his relationship with his wife as sustainable, you might well pity them both'. ${ }^{132}$ They also criticize the view that we should address environmental problems simply by being more efficient and polluting less - by being 'less bad'. ${ }^{133}$ While eco-efficiency 'is an outwardly admirable, even noble concept', they argue, 'it is not a strategy for success over the long term, because it does not reach deep enough'. ${ }^{134}$ 'The key is not to make human industries and systems smaller, as efficiency advocates propound, but to design them to get bigger and better in a way that replenishes, restores, and nourishes the rest of the world'. 135

McDonough and Braungart build on these themes in their 2013 book, The Upcycle: Beyond Sustainability - Designing for Abundance. ${ }^{136}$ 'The goal of the upcycle', they say, 'is a delightfully diverse, safe, healthy and just world with clean air, water, soil, and power - economically, equitably, ecologically, and elegantly enjoyed'. ${ }^{137}$ '[A]t this point in history, after so much damage has been done, people don't need to have less of a negative environmental footprint: They can have

129 Another approach is based on regenerative development: see, e.g., J. Tillman Lyle, Regenerative Design for Sustainable Development (Wiley, 1994).

130 N. Lugaresi, 'The Unbearable Tiredness of Sustainable Development (At Different Levels, Lately)', in R.V. Percival, J. Lin \& W. Piermattei (eds), Global Environmental Law at a Crossroads (Edward Elgar, 2014), pp. 195-210.

131 W. McDonough \& M. Braungart, Cradle to Cradle: Remaking the Way We Make Things (North Point Press, 2010), p. 155.

132 Ibid.

133 Ibid., at pp. 45-67.

134 Ibid., at pp. 61-2.

135 Ibid., at p. 78.

136 W. McDonough \& M. Braungart, The Upcycle: Beyond Sustainability - Designing for Abundance (North Point Press, 2013).

137 Ibid., at p. 12. 
a positive footprint' ${ }^{138}$ Their consistent message is the enormous potential of this approach through creativity and imagination:

The possibilities here are very exciting: Our world can be made truly clean, safe, and healthy when designers, engineers, and businesses embrace innovation that grows the good, not by continuing conventional production, making things somewhat 'less bad' and watching the metrics improve bit by bit. ... Instead of this confusing perspective, what if ambitions were stated as: 'How can I select and use 100 percent positively defined materials and renewable energy? How can I increase prosperity, celebrate my community, and enhance the health of all species? ... The results can be astoundingly positive and enriching. ${ }^{139}$

Andrés Edwards, a sustainability consultant and writer, sets out a similar perspective in Thriving Beyond Sustainability: Pathways to a Resilient Society: 'Sustainability separates us from nature and envisions us "getting by" by limiting our negative environmental impacts over the long term'. ${ }^{140}$ 'Thriveability', by contrast, 'embodies the innate qualities that define our humanity - our capacity for empathy, compassion, collaboration, playfulness, creativity, enthusiasm and love'. ${ }^{141} \mathrm{He}$ continues: 'The thriveable perspective asks, "How can we satisfy basic human needs such as food, water, shelter, education, healthcare and love for all people on the planet while creating a meaningful life?",142 For Edwards, thriveability drives better outcomes: 'Instead of a net-zero energy home, the thriveable goal is a home that generates more electricity than it uses; instead of restoring an ecosystem in decline, the thriveable goal is to regenerate it so that it teems with diverse wildlife and is integrated with flourishing human settlements'. ${ }^{143}$

In spite of these authors' criticisms of sustainability, their thinking largely tracks the sustainable development decision-making framework described above. When Edwards asks how we can satisfy basic human needs, he is posing the exact question the Brundtland Commission posed. When McDonough and Braungart ask how we can design 'not just for health but for abundance, proliferation [and] delight', ${ }^{144}$ they plainly endorse, at a minimum, the satisfaction of human needs. These authors all recognize the importance of an approach that combines environmental protection, social well-being and economic development. $^{145}$ When Edwards combines human needs with regenerated

138 Ibid., at p. 36

139 Ibid., at p. 81. An example is agriculture: 'We might create farming techniques that sustain the longest period of productivity, augment the soil for optimal plant growth, utilize soil in the most compact way, and diversify the design of that growth for different locations': ibid., at p. 125. To scale up the use of their ideas in specific contexts, McDonough and Braungart have established a Cradle to Cradle Products Innovation Institute and a Cradle to Cradle certification programme for qualifying products: ibid., at pp. 198-9; see also Cradle to Cradle Products Innovation Institute at: http://www.c2ccertified.org.

140 A. Edwards, Thriving Beyond Sustainability: Pathways to a Resilient Society (New Society, 2010), p. 149 .

141 Ibid., at pp. 4-5.

142 Ibid., at p. 165.

143 Ibid., at pp. 164-5.

144 McDonough \& Braungart, n. 136 above, at p. 11. 
ecosystems, he is employing the integrated decision-making framework that is central to sustainable development. Similarly, McDonough and Braungart say that 'we have come to see that human beings are essentially in agreement on what is needed to integrate ourselves into the natural upcycle of life'. ${ }^{146}$ They all identify intergenerational equity ${ }^{147}$ and the precautionary approach ${ }^{148}$ as essential to their life-affirming visions. As explained above, both of these principles are key to sustainable development.

These authors seem focused on a relatively discrete subset of activities, which include building design and architecture, community planning, landscaping, and product design. While sustainability can accommodate terms such as 'thriveable' in those contexts, such terms are not likely to work as effectively as 'sustainability' or 'sustainable development' in other contexts. For example, while we may doubt that the fish labelled 'sustainable' at our local grocery store were, in fact, harvested in a manner consistent with sustainabilitybased decision-making, there are questions we can ask to lead us to a more informed opinion. We can ask whether, in light of current harvest rates and methods, future generations of people will have the option of purchasing the fish, as we do. ${ }^{149}$ If the fish were labelled 'thriveable', we would have no idea whether to buy it or not.

In addition, the implication that 'mere' sustainability necessarily discourages ecological restoration - homes that generate energy and other 'net positive' activities is wrong. The objective of sustainable development is human well-being, and all of these activities contribute to that objective. Moreover, as previously explained, the term does not automatically imply any particular environmental goal; they vary from issue to issue and place to place. There is nothing in the history of the term that explicitly limits sustainability goals to merely being 'less bad'. Furthermore, by opening up a space for developing and implementing laws, policies, technologies, and other actions that maximize the net environmental and development benefits of particular actions, sustainable development makes possible more abundant and thriveable outcomes.

Still, it is not hard to see the origins of this misunderstanding. In the context of the continuing and widespread global environmental degradation against which the term 'sustainable development' originated, 'sustainable' describes a minimum system condition for environmental quality and resource availability; it is a damage control term.

145 Ibid., at p. 147 ('[W]e know that if you put people, planet, and profit at the triple top line [meaning that they are an organization's 'top values'], good effects cascade down and outward'); Edwards, n. 140 above, at p. 48 (describing the business community's embrace of the triple bottom line as a 'milestone' in its change towards more thriveable practices).

146 McDonough \& Braungart, n. 136 above, at p. 214.

147 Ibid., at p. 9; Edwards, n. 140 above, at pp. 155-7.

148 McDonough \& Braungart, n. 136 above, at p. 217; Edwards, ibid., at pp. 161-3.

149 We can also ask whether current harvesting techniques damage ecosystems even if that damage does not directly affect the number of fish available to buy now or in the future (ecological integrity). We can ask whether the money we pay for the fish will be distributed equitably among the humans who have brought it to our local grocery store (social justice). We can ask whether uncertainties associated with the environmental and human impacts of our potential purchase have been considered and how they have been taken into account (precautionary approach). We can also discover whether the local grocery store is even capable of answering the questions (public participation). 
The primary task of doctors and other medical professionals in a hospital emergency room, where many patients have experienced a serious or life-threatening injury or condition, is to stabilize their condition. ${ }^{150}$ Stabilizing their condition will, hopefully, enable them to recover their health. Similarly, many environmental conditions on the planet would be vastly improved if they were now merely sustainable. As already explained, these include, but are not limited to, GHG emissions and the loss of biodiversity. ${ }^{151}$ In that sense, sustainability is more ambitious than it might at first appear, and continually making things 'less bad' is an essential task. Yet, it is not the same as healthy or abundant.

Against these challenges - when the overwhelming temptation of decision makers is to slow down the rate at which environmental quality gets worse, and when reducing damage to an acceptable level seems the best possible outcome - these critics ask decision makers to be both more ambitious and more positive than they might otherwise be inclined to be. The urgency of many of the challenges that confront us makes these voices important. They can, for example, prod decision makers towards breakthrough improvements as opposed to being satisfied with incremental improvements.

These critics also capture a core truth about the transition to sustainability. The transition is likely to be more effective, more enduring, and broader in scale if it is seen not as somewhat more attractive than our current situation, but as vastly more attractive; so much better that it provides the momentum or impetus to overcome all of the various obstacles that stand in the way. While sustainable development requires much more than new technologies, the diffusion of recently developed technologies provides a way of understanding how the transition to sustainability needs to work. ${ }^{152}$ In a very short period of time, personal computers virtually displaced typewriters, and mobile phones largely displaced conventional phones. They did so because they offer enormous advantages over the technologies they displaced. One can imagine a similarly rapid transition away from fossil fuel-based electricity and towards renewable energy if the price of solar or wind power technologies were to fall significantly below current market rates and these technologies were deployed at scale. Alternatives of the kind suggested by these authors, which would probably need to be facilitated by appropriate enabling laws, could also accelerate the transition to sustainability.

More broadly, these critics suggest that the term is not sufficiently motivational. Of course, as suggested above, attractive futures and alternatives are motivational; but so are threats and risks, particularly if they are sufficiently large and immediate.

150 See Education Portal, 'Emergency Physician: Job Description and Educational Requirements', available at: http://education-portal.com/articles/Emergency_Physician_Job_Description_and_ Educational_Requirements.html.

151 See also G. Harris, 'Delhi Wakes Up to Problem It Cannot Ignore', The New York Times, 15 Feb. 2015, p. 6, available at: http://tinyurl.com/delhiprob (describing extremely unhealthy levels of air pollution in Delhi (India)); D. Fears, 'Clawing Their Way Back', Sunday Patriot-News (Harrisburg, PA (US)), 15 Feb. 2015, p. A19 (describing the recent steep decline in the population of blue crabs in Chesapeake Bay); V. Mallet, 'The Ganges: Holy, Deadly River', Financial Times Magazine, 3 Feb. 2015, available at: http://tinyurl.com/FT-ganges (describing the extensive and continuing pollution of the Ganges River).

152 E. Rodgers, Diffusion of Innovations, $5^{\text {th }}$ edn (The Free Press, 2003). 
The challenge for sustainability is that most of its threats are cumulative and unfold over time, and therefore tend to lack the same urgency as military or terrorist attacks. This suggests the need for a variety of other tools to convey the urgency of sustainability and motivate appropriate changes, including better information about the impacts of unsustainable development, better communication of those impacts, and greater use of behavioural mechanisms to 'nudge' people and institutions towards sustainability.

\subsection{Too Vague}

By far the most common criticism of the concept of sustainability is that, after 35 years of discussion, we are still unable to reduce it to a universally comprehensible formula. For many people, sustainability is simply another word for something 'green', adding only a 'buzzword' but nothing of substance to the conversation. These criticisms often reflect little awareness of the historical origin of sustainability - either on the part of the person or organization that claims to be acting in a sustainable way, of the critic, or both. Plugging the word 'sustainability' into the Google Ngram Viewer (which charts the frequency of the use of words and phrases in books digitized in the Google Books Project) shows the dramatic rise in usage of the term. 'Sustainable development' has followed a similar, if slightly less spectacular, trajectory. ${ }^{153}$ Words and phrases used so frequently in so many contexts must, inevitably, be misused. Unfortunately, this lack of awareness is shared to a varying degree by legislators. A wide variety of 'sustainability' definitions have been enacted into law. ${ }^{154}$

Yet sustainable development has a relatively definite meaning, as explained in Part 2 of this article. Because sustainable development is intended to integrate development with environmental protection, environmental protection is at its core. Still, the critiques are helpful in identifying gaps in the framework and suggesting ways to address them.

Claims about the vagueness of sustainability fall into several categories, some of which are easier to answer than others. Some argue that sustainability can mean anything at all, and therefore means nothing. ${ }^{155}$ Given numerous actual examples of obviously unsustainable development, however, sustainability cannot embrace everything. ${ }^{156}$ For instance, continued high levels of GHG emissions, or clearing a

153 N. 6 above.

154 See, e.g., 42 U.S.C. $\ 6371$ h-1('The term “energy sustainability” includes using a renewable energy source, thermal energy source, or a highly efficient technology for transportation, electricity generation, heating, cooling, lighting, or other energy services in fixed installations'); California Water Code $\$ 10721$ (defining 'sustainable groundwater management' to mean 'use of groundwater in a manner that can be maintained during the planning and implementation horizon without causing undesirable results'); Minn. Stat. Ann. $\$ 17.114$ (“"Sustainable agriculture” represents the best aspects of traditional and modern agriculture by using a fundamental understanding of nature as well as the latest scientific advances to create integrated, self-reliant, resource conserving practices that enhance the enrichment of the environment and provide short- and long-term productive and economical agriculture').

155 See, e.g., H. Farley \& Z. Smith, Sustainability: If It's Everything, Is It Nothing? (Routledge, 2014).

156 Note that similar arguments are made about the meaning of freedom or justice. Each has a certain core meaning, however general that meaning may be. As Amartya Sen explains, we can identify specific examples of injustice long before we can explain conceptually what justice means: Sen, n. 64 above, at pp. vii-viii. 
rain forest and causing the impoverishment of the people living there, are not likely to fit any reasonable observer's definition of sustainable development. If sustainable development could mean anything at all, it would include these examples.

Others see the term as an oxymoron: development, they say, is inconsistent with environmental protection. If sustainable development is synonymous with sustainable growth, then it truly is an oxymoron. ${ }^{157}$ Sustainable growth is a business term for an optimal growth rate. Growth, particularly conventional economic growth, is a driver for unsustainable development. However, sustainable growth is not sustainable development because growth is not a framework for integrated decision making and because it is not directed expressly at human well-being.

A broader but similar version of this argument is based on historical precedent. Because conventional development damages the environment and people who depend on the environment, the argument goes, combining development with environmental protection is incoherent. ${ }^{158}$ Yet the point of sustainable development is to transform conventional development, not to relabel it. The premise of sustainable development is that such a transformation is possible, indeed necessary. The challenge this presents to the modern world view, which is based on overwhelming evidence that development occurs only at the expense of the environment and the people who depend on it, cannot be overstated. Many simply do not believe that humans can or should live in harmony with nature rather than at nature's expense.

The problem is similar to that presented by new scientific paradigms, and is likely to be resolved in a similar way. New scientific paradigms are based on, and therefore require, changes in world view. ${ }^{159}$ As a result, they require scientists to choose between the old and the new paradigm. Many who are wedded to the old paradigm will fail to understand the new one and will resist. If supporters of the new paradigm 'are competent, they will improve it, explore its possibilities, and show what it would be like to belong to the community guided by it'. In time, if all goes well for them, they will gain more supporters and practitioners, until eventually the new paradigm prevails. ${ }^{160}$ Similarly, a large and growing body of sustainable development practitioners (including lawyers and lawmakers) are working out the meaning of the term in specific contexts, and are devising and continually improving a variety of practices directed towards sustainable development. If sustainability succeeds, it will do so because more and more practitioners adopt its conceptual framework, until eventually conventional development becomes a relic.

The challenge that sustainability presents to its critics is to improve and strengthen the framework as well as its application in specific places and sectors, and not simply to criticize it. That is the process by which a great many ideas related to environmental

157 H. Daly \& K. Townsend, Valuing the Earth: Economics, Ecology, Ethics (The MIT Press, 1993), p. 267.

158 R. Kates, T. Parris \& A. Leiserowitz, 'What is Sustainable Development? Goals, Indicators, Values, and Practice' (2005) 47(3) Environment: Science and Policy for Sustainable Development, pp. 8-21, at 20.

159 T. Kuhn, The Structure of Scientific Revolutions, 4th edn (University of Chicago Press, 2012), pp. 111-34.

160 Ibid., at pp. 157-8. 
protection have grown in clarity and sophistication over time. For example, protection of wetlands in the US can be traced to a 1907 publication in which the term 'wetland' was used as a 'euphemistic substitute for the term swamp'. ${ }^{161}$ The first official use of the term was in a 1956 circular issued by the Fish and Wildlife Service. ${ }^{162}$ Now the US has a sophisticated wetlands protection programme. ${ }^{163}$ In sustainable development, there is considerable evidence that improvements in the framework and its application to specific situations are occurring more quickly than they did for wetlands.

Another and persistent line of criticism is that the sustainable development framework does not provide a complete programme that one can simply follow. ${ }^{164}$ It is true that many of the questions that must be answered to achieve sustainability are not answered by the sustainability framework, or are answered only partially. That, however, is a strength of the framework, not a weakness:

[S] ustainable development draws much of its resonance, power, and creativity from its very ambiguity. The concrete challenges of sustainable development are at least as heterogeneous and complex as the diversity of human societies and natural ecosystems around the world. As a concept, its malleability allows it to remain an open, dynamic, and evolving idea that can be adapted to fit these very different situations and contexts across space and time. ${ }^{165}$

There is no precise and complete one-size-fits-all programme for sustainability, and gaps remain to be filled. Nonetheless, the sustainability approaches that have been developed for specific issues - including sustainable forestry, green building, and corporate sustainability reporting - do provide reasonably complete programmes to follow in those contexts. These specific approaches, all of which are based on the overall sustainability framework, are continually being developed and improved. In turn, the overall sustainability framework provides a benchmark to analyze and evaluate whether these specific approaches are truly sustainable.

Other 'vagueness' critiques are based on the argument that sustainability is not sufficiently protective of the environment - vagueness as 'greenwashing'. This argument is similar but not identical to the claims about the limited psychological appeal of 'mere sustainability'. Instead, the claim of the 'vagueness as greenwashing' critics is that sustainability dilutes or weakens environmental protection. There are at least two related lines of argument.

The first line of the 'vagueness as greenwashing' criticism draws on a distinction by economists between 'weak sustainability' and 'strong sustainability'. According to the weak sustainability perspective, 'the next generation should inherit a stock of wealth, comprising man-made assets and environmental assets, no less than the stock inherited by the previous generation'. ${ }^{166}$ The strong sustainability perspective,

161 NRC, Wetlands: Characteristics and Boundaries (National Academies Press, 1995), p. 43.

162 Ibid., at p. 48.

163 For a comprehensive overview of these programmes, see M. Strand \& L. Rothschild, Wetlands Deskbook, $3^{\text {rd }}$ edn (ELI, 2010).

164 See, e.g., Kates, Parris \& Leiserowitz, n. 158 above, at p. 20.

165 Ibid.

166 D. Pearce, A. Markandya \& E. Barbier, Blueprint for a Green Economy (Earthscan, 1989), p. 34. 
by contrast, is that 'the next generation should inherit a stock of environmental assets no less than the stock inherited by the previous generation'. ${ }^{167}$ Weak sustainability differs from strong sustainability in that it permits the depletion of natural stock or capital (such as forests or wetlands) so long as the total stock of human and natural capital for the next generation (including buildings or products made from forests and development based on filling the wetland) is at least as great as that available to the present generation. 'According to the weak sustainability view, there is no essential difference between natural and other forms of capital, hence the same optimal depletion rules ought to apply to both' ${ }^{168}$ Thus, weak sustainability offers a vastly lower level of environmental protection than does strong sustainability, if it provides any environmental protection at all. The deforestation of the US from colonial times to the $20^{\text {th }}$ century could be justified on weak sustainability grounds because of its contribution to economic development and capital formation. ${ }^{169}$

Forms of weak sustainability find expression in a variety of contexts. Robert Engelman suggests that sustainability has become almost meaningless 'sustainababble'. ${ }^{170} \mathrm{He}$ writes: 'Today the term sustainable more typically lends itself to the corporate behavior often called greenwashing. Phrases like sustainable design, sustainable cars, even sustainable underwear litter the media'. ${ }^{171}$ Indeed, advocates of strong sustainability often portray weak sustainability as an effort by corporate and business interests particularly to water down the meaning, and therefore the impact, of sustainability. ${ }^{172}$

The strong sustainability perspective is more closely aligned with the historical understanding of sustainable development. Many natural assets perform functions that cannot be replicated, no matter how much capital a society accumulates. ${ }^{173} \mathrm{We}$ have known for several decades that the total economic value of 'nature's services', including the watershed protection function of forests and the role of microorganisms in creating and maintaining soil, is enormous. ${ }^{174}$ Scientific uncertainty about the existence and extent of all of these natural services counsels caution about depleting them. ${ }^{175}$ Once they are lost (for example, a species), they cannot be replaced. ${ }^{176}$ Finally, protection of natural capital is particularly important for many of the poor because they 'tend to be more dependent on natural resources' for

167 Ibid.

168 D. Pearce \& E. Barbier, Blueprint 6: Blueprint for a Sustainable Economy (Earthscan, 2000), p. 24.

169 See T. Cox et al., This Well-Wooded Land: Americans and Their Forests from Colonial Times to the Present (University of Nebraska Press, 1985).

170 R. Engelman, 'Beyond Sustainababble', in E. Assadourian (ed.), State of the World 2013: Is Sustainability Still Possible? (Island Press, 2013), pp. 3-16, at 3.

171 Ibid. (emphasis omitted).

172 See, e.g., E.J. Yanarella \& R.S. Levine, 'From Sustainability to Resilience: Advance or Retreat?' (2014) 4(7) Sustainability, pp. 197-208.

173 Pearce, Markandya \& Barbier, n. 166 above, at pp. 37-8.

174 The classic article on this topic remains R. Costanza et al., 'The Value of the World's Ecosystem Services and Natural Capital' (1997) 387(6630) Nature, pp. 253-60 (estimating the value of ecosystem services at an average of $\$ 33$ trillion per year, compared with global gross national product of $\$ 18$ trillion per year).

175 Pearce, Markandya \& Barbier, n. 166 above, at p. 38.

176 Ibid. See also Pearce \& Barbier, n. 168 above, at p. 23 (stating other uncertainties in determining 'whether environmental resources are being exploited sustainably and efficiently over time'). 
their livelihoods. ${ }^{177}$ Although some substitution of natural capital for human-made capital is inevitable and desirable even in a sustainable society, a stronger form of sustainability is preferable to a weaker version, and is more consistent with the evolving understanding.

A second 'vagueness as greenwashing' criticism relates to the weight given to the environment when environmental, social, and economic considerations are brought together in decision making. We agree that the proper approach to trade-offs among the environmental, social, and economic dimensions of sustainability is an important and often overlooked issue. Much of the sustainability dialogue is about 'win-win-win' outcomes - meaning that a decision maker can improve environmental quality, save money, and create jobs in the same decision. Such outcomes should be possible, even easy, on many sustainability issues, such as energy conservation and efficiency. One reason why trade-offs do not receive more attention is that much of sustainability's 'low-hanging fruit' has not been harvested; in these cases trade-offs do not present a difficult issue.

The sustainable development literature does address trade-offs in harder cases. The rules relating to trade-offs include systems that allow better outcomes in one aspect of a proposal to totally or partially compensate for poorer outcomes in another aspect of the proposal. A different approach is to prohibit 'natural or environmental capital' from being 'traded off against produced or manufactured capital'. ${ }^{178}$ A somewhat similar rule is that 'trade-off decisions must not compromise the fundamental objective of net sustainability gain'. ${ }^{179}$ The first of these rules, which could allow better economic outcomes to compensate for poorer social and environmental outcomes, shows how trade-off rules, if not handled correctly, can lead straight back to conventional development.

Several authors who are critical of sustainable development and its potential for greenwashing argue that trade-offs should be addressed simply by putting the environment first. Heather Farley and Zachary Smith argue that sustainability is not sufficiently protective of the environment: 'Sustainability has been co-opted into the sustainable development discourse where development is first and foremost about human survival and meeting human needs, but does not necessarily have much to do with genuine sustainability, which is reliant upon the continuation of the earth'. ${ }^{180}$ The solution, Farley and Smith claim, is not to abandon sustainability but to adopt 'a stricter interpretation' of the term that corrects 'the broad interpretation'. ${ }^{181}$ They call their modification 'neo-sustainability', which is 'the ability of an activity to sustain a system by improving its quality and operating within its limits'. ${ }^{182}$

177 Ibid., at pp. $38-40$.

178 Organisation for Economic Co-operation and Development (OECD), Guidance on Sustainability Impact Assessment (OECD, 2010), p. 22.

179 R. Gibson, 'Sustainability Assessment: Basic Components of a Practical Approach' (2006) 24(3) Impact Assessment and Project Appraisal, pp. 170-82, at 175; see also R. Gibson et al., Sustainability Assessment: Criteria and Processes (Earthscan, 2005), pp. 176-8, 237-8.

180 Farley \& Smith, n. 155 above, at p. 150.

181 Ibid., at p. 163.

182 Ibid., at p. 151. 
Because 'the environmental system is foundational', ${ }^{183}$ the three rules they posit for neo-sustainability all relate to the environment:

1. Limits: there are natural limits to growth.

2. Environmental primacy: these limits are dictated by the environment, and therefore actions in any system must adhere to the carrying capacity of the earth's natural systems.

3. Systems thinking: because environmental, economic and social systems are nested systems, actions must be based on systems thinking, which accounts for multi-level impacts and the influences that generate impacts. ${ }^{184}$

The 'cradle to cradle' model described above is one of several 'commonly adopted frameworks' that, in their view, support 'the rules of neo-sustainability'. ${ }^{185}$

Klaus Bosselmann has a similar critique of how sustainability has been applied, and a somewhat similar proposal. ${ }^{186} \mathrm{He}$ is most critical of an understanding of sustainability that involves trading off social, economic, and environmental concerns. To the extent that sustainability is understood that way, he argues, it is meaningless because it provides no guidance for how such trade-offs should occur. 'Clarity', he says, "can only come from defining the essence of "sustainable" with respect to its object. The essence is neither "economic sustainability", nor "social sustainability", nor "everything sustainable", but "ecological sustainability", 187 The core meaning of sustainability, in other words, is 'ecological integrity' ${ }^{188}$ According to Bosselmann, the relationship of the social, economic, and environmental aspects of sustainability can be summarized as '[n]o economic prosperity without social justice and no social justice without economic prosperity, and both within the limits of ecological sustainability'. ${ }^{189}$

In a fundamental way, these critiques are less about the concept of sustainable development than they are about how some individuals and organizations apply the term. As Bosselmann recognizes, any version of sustainability that simply involves a balancing of economic, social, and environmental objectives is inconsistent with the

183 Ibid.

184 Ibid.

185 Ibid., at pp. 158, 162. Other frameworks that support their approach include Kenneth Boulding's 'spaceman economy', in which 'the earth is a closed system much like a spaceship': ibid., at p. 158. See K.E. Boulding, 'The Economics of the Coming Spaceship Earth', in H. Jarrett (ed.), Environmental Quality in a Growing Economy (Resources for the Future/Johns Hopkins University Press, 1966), pp. 3-14. Another is the Natural Step Framework - a framework for sustainable practices which establishes 'four system conditions for sustainability' that are broadly consistent with environmental primacy: Farley $\&$ Smith, n. 155 above, at p. 159. Still another is environmental justice, because environmental degradation hurts other people: ibid., at pp. 160-2. Finally, neo-sustainability has the potential to reduce the ecological footprint - 'a representation of an organization's or individual's demand on the earth's ecosystems' - of individuals and societies: ibid., at p. 162.

186 Bosselmann, n. 12 above, at pp. 43-77.

187 Ibid., at pp. 52-3.

188 Ibid., at p. 76. Put differently, 'development is sustainable if it tends to preserve the integrity and continued existence of ecological systems; it is unsustainable if it tends to do otherwise': ibid.

Ibid. 
historical context in which the term originated. ${ }^{190}$ Widespread and growing environmental degradation was a basic reason why development needed to be made sustainable. The whole point of sustainable development is to integrate development with environmental protection. Thus, any application of sustainability that does not have environmental protection at its core, we argue, is simply wrong.

By their insistence on the importance of 'environmental primacy' and 'ecological integrity', these critics reduce the likelihood that environmental protection will be diluted by balancing social, environmental, and economic goals within the larger frame of sustainable development. Public and private decision makers are free, within the sustainability framework, to adopt environmental goals of the kind advocated by these critics. This is fully consistent with that framework because, as already explained, more robust environmental goals are more likely to enlarge human freedom, opportunity, and quality of life.

That said, an understanding of sustainable development based on putting the environment first must come to terms with the social dimension of sustainability reducing and eliminating extreme poverty - and more broadly with the challenge of improving human well-being. While environmental protection is at the core of sustainability, so too is the social dimension. This urges consideration of more nuanced trade-off rules which attempt to give full effect to each dimension of sustainability, as several rules from the sustainable development literature appear to do. More generally, it is essential for decision makers to be transparent with the public and their stakeholders about the trade-off rules that they do employ.

A final source of claims that the vagueness of sustainability accommodates greenwashing is provided by the use of sustainability-sounding concepts in law that do not, in practice, protect the environment or achieve sustainable development. The US Federal Multiple-Use Sustained-Yield Act of $1960^{191}$ defines 'sustained yield' of products and services to mean 'the achievement and maintenance in perpetuity of a high level annual or regular periodic output of the various renewable resources of the national forests without impairment of the productivity of the land'. Sustained yield has deep roots in forestry and related natural resource fields. ${ }^{192}$ Sustained yield is not sustainable development or sustainability, however. At its best, 'sustained yield' requires perpetual output of specific resources without obvious damage to the ecosystems that produce them; otherwise, its history is almost entirely distinct from the history of sustainable development. It does not require integrated decision making. On the contrary, it militates in favour of simplified decision making based on projected yield of specific resources and emphasizes high levels of production. It requires consideration of neither social justice nor economic viability.

Despite its limitations, sustained yield is a popular concept in US federal law. The US Forest Service commitment to sustained yield is reaffirmed in the National Forest

\footnotetext{
190 Ibid., at pp. 55-7.

19116 U.S.C. $\$ \mathbb{S} 528-531$.

192 S. Hayes, Conservation and the Gospel of Efficiency (University of Pittsburgh Press, 1999), p. 28.
} 
Management Act. ${ }^{193}$ The Federal Land Management and Policy Act of 1976 extended the concept of sustained yield to public lands subject to the jurisdiction of the US Department of the Interior. ${ }^{194}$ Additional legislation requires sustained yield in the management of American Indian forest land. ${ }^{195}$ The concept has migrated beyond the realm of forestry in which it emerged. The Magnuson-Stevens Fisheries Conservation and Management Act requires each Regional Fishery Management Council $^{196}$ to prepare fishery management plans regarding fisheries within its responsibility. Each fisheries management plan must specify 'the maximum sustainable yield and optimum yield from ... the fishery'. ${ }^{197}$ The statute includes a definition of 'optimum' with respect to the yield from a fishery, but it provides no definition of 'maximum sustainable yield'. 198

To add to the confusion, the CBD defines 'sustainable use' as 'the use of components of biological diversity in a way and at a rate that does not lead to the long-term decline of biological diversity, thereby maintaining its potential to meet the needs and aspirations of present and future generations'. ${ }^{199}$ While rooted in sustainable development, the CBD's use of the word 'rate' echoes sustained yield thinking.

It is extremely important to maintain a distinction between 'sustained yield' and 'sustainable development'. Sustained yield is a narrow goal, arguably demonstrable through evidence of long-term consistent harvest levels. Sustainable development requires an integrated decision-making framework, which prescribes no specific goals and requires consideration of a range of factors often ignored in sustained yield planning.

\subsection{Too Late}

The final criticism - one that has been voiced more frequently in recent years - is that in some fundamental way it is too late to make sustainability work and that current and future conditions make sustainable development impossible. Some critics base their assessment on an overall worsening of environmental conditions, while others focus on climate disruption. All find a touchstone in 'resilience', which they believe to be more realistic and appropriate than sustainability. Some would replace sustainability with resilience in every context; others would place greater emphasis on resilience, but would not abandon sustainability. We fear that adopting resilience as a substitute for sustainable development would allow decision makers to ignore human well-being, persistent global poverty, and social equity. Without using the term, this shift allows decision makers to adopt 'lifeboat ethics', ${ }^{200}$ where the

\footnotetext{
19316 U.S.C. $\$ 1607$.

19443 U.S.C. $\$ 1732(\mathrm{a})$.

19525 U.S.C. $\$ 3104(b)(1)$.

19616 U.S.C. $\$ 1852$.

19716 U S.C. $\$ 1853(\mathrm{a})(3)$.

19816 U.S.C. $\$ 1802(33)$.

199 Art. 2 CBD, n. 40 above.

200 G. Hardin, 'Lifeboat Ethics: The Case Against Helping the Poor', Psychology Today, Sept. 1974, pp. 38-43, 123-6, available at: http://www.garretthardinsociety.org/articles/art_lifeboat_ethics_case_ against_helping_poor.html.
} 
preservation of a few people can justify abandoning many. As thus applied, resilience allows us to turn a blind eye to social justice. Sustainability does not.

The idea of resilience has its roots in the analysis of ecological systems. ${ }^{201}$ Since its inception, the concept has been utilized effectively in many scientific fields, from mechanics to psychology. The essential idea is that consumer goods and societal infrastructures can and should be constructed in a manner that is resilient to the inevitable adverse effects of future events. ${ }^{202}$ This concept stresses the importance of durability and elasticity in social design. In reports on disasters and coastal risk in 2012 and 2014, the National Academy of Sciences defined resilience as 'the ability to prepare and plan for, absorb, recover from, and more successfully adapt to adverse events'. ${ }^{203}$ Dennis Meadows, one of the authors of the influential 1972 Club of Rome Report, The Limits to Growth, ${ }^{204}$ has described resilience as the 'capacity of a system to absorb shocks and to continue functioning. ${ }^{205}$

Meadows believes that resilience should replace sustainability. He has come to believe that some collapse of civilization has become inevitable as we have continued to increase population and resource consumption over the past four decades. His view of sustainable development, he says, is based on popular understanding:

When I use the term sustainable development - which I consider to be an oxymoron actually - I am trying to capture the meaning that most people seem to have. In so far as I can tell, people who use the term mean, essentially, that this would be a phase of development where they get to keep what they have but all the poor people can catch up. Or, they get to keep doing what they've been doing, but through the magic of technology they are going to cause less damage to the environment and use fewer resources. ${ }^{206}$

As Meadows sees it, it is too late for sustainable development: 'Either way you use the term, it [sustainable development] is just a fantasy. Neither of those is possible anymore. It probably was possible back in the '70s, but not now. We're at 150 percent of the global carrying capacity'. ${ }^{207}$ The chaotic economic downturns accompanying the collapse of the dot-com and housing bubbles made it clear to him 'that we just haven't got a chance of dealing with these issues in any kind of orderly way'. The Limits to Growth, he explains, was about a much bigger

201 C.S. Holling, 'Resilience and Stability of Ecological Systems' (1973) 4 Annual Review of Ecology \& Systematics, pp. 1-23, at 14 (defining resilience as 'a measure of the persistence of systems and of their ability to absorb change and disturbance and still maintain the same relationships between populations or state variables').

202 See J. Fiksel, 'Sustainability and Resilience: Toward a Systems Approach' (2006) 2 Sustainability: Science, Practice \& Policy, pp. 14-21, at 16 (defining resilience as 'the capacity of a system to tolerate disturbances while retaining its structure and function'). See also Yanarella \& Levine, n. 172 above, at p. 199 (providing a typology of resilience in different contexts).

203 NRC, Reducing Coastal Risk on the East and Gulf Coasts (National Academies Press, 2014), p. 19; NRC, Disaster Resilience: A National Imperative (National Academies Press, 2012), p. 1. See also Fiksel, ibid.

204 D.H. Meadows et al., The Limits to Growth: A Report for the Club of Rome's Project on the Predicament of Mankind (Universe Books, 1972).

205 M. Gambino, 'Is It Too Late for Sustainable Development?', interview with Dennis Meadows, Smithsonian.com, 15 Mar. 2012, available at: http://tinyurl.com/GambinoSD.

206 Ibid.

207 Ibid. 
bubble - 'a bubble in population and in material and energy consumption'. ${ }^{208}$ Because we are also unlikely to deal effectively with the collapse of that bubble, long-term resilience is necessary. ${ }^{209}$ A similar sentiment has been voiced by environmental writer Bill McKibben, leader of 350.org, a worldwide grassroots organization dedicated to fighting climate change, who now speaks about 'surviving not thriving. ${ }^{210}$

Robin Kundis Craig and Melinda Harm Benson also argue that sustainability should be replaced by resilience. ${ }^{211}$ Their understanding of sustainability is grounded in assumptions of ecological 'stationarity'. As 'a matter of basic linguistic definition, sustainability is about human efforts to maintain continuity and keeping things natural resources - in the same state of being as when management started or with reference to this baseline'. ${ }^{212}$ In addition, they say, 'sustainability assumes that baseline environmental conditions - temperature, precipitation, soil moisture, species mix, and so forth - will remain more or less the same, within natural variability envelopes, over long periods of time'. ${ }^{213}$

This approach, they contend, is an 'increasingly futile goal' in the face of climate change, as 'climate change significantly undermines sustainability as a governance paradigm'. ${ }^{214}$ According to Craig and Benson, 'climate change is creating a world of non-stationarity - a world where baseline conditions in the natural world can no longer be assumed'. ${ }^{215}$ A better course is based on the 'concept of resilience and the theory of resilience thinking', which 'offers a new and potentially more productive orientation than sustainability to the environmental challenges ahead'. ${ }^{216}$ They explain: 'Resilience thinking assumes that systems are continually responding and adapting to continual change, with the ever present possibility that the changes will cross a threshold and induce an abrupt regime shift in the system, ${ }^{217}$ What is needed, they say, is 'a new governance structure that thoroughly incorporates resilience thinking. The design must address the need for adaptive capacity and administrative flexibility while also providing the necessary strong and enforceable frameworks that will be sufficiently supportive of the [socio-ecological] system states that we seek to foster and protect'. ${ }^{218}$

Resilience unquestionably needs greater attention, particularly because of ongoing and projected future climate change. GHGs in the atmosphere are now higher than they have been in at least 800,000 years. ${ }^{219}$ Even if we stop emitting carbon dioxide $\left(\mathrm{CO}_{2}\right)$ and other GHGs now, $\mathrm{CO}_{2}$ already in the atmosphere would stay there for

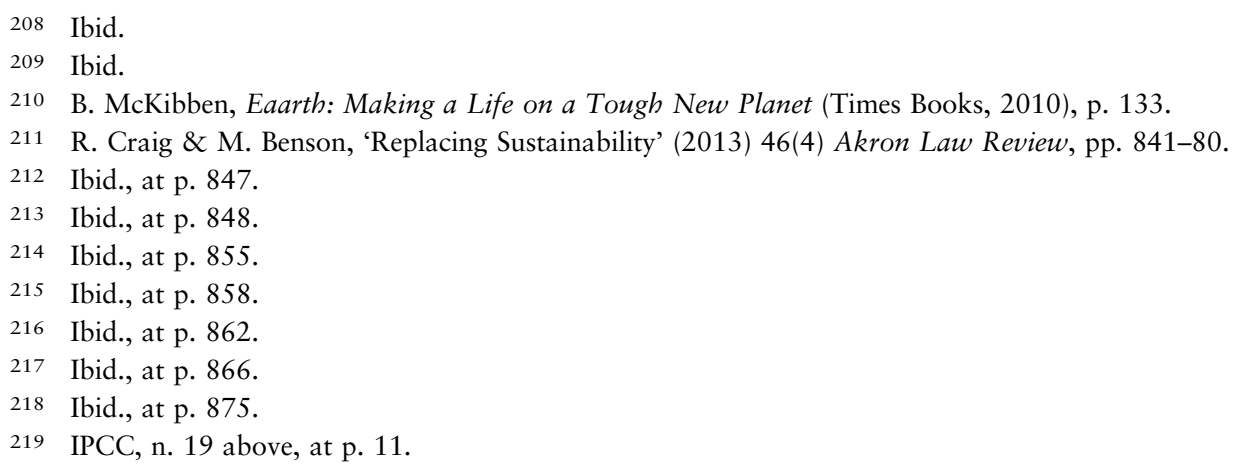


hundreds or thousands of years unless we find a way to remove it. ${ }^{220}$ There is also no question that climate disruption and resilience loom larger now than they did in 1992. The central contribution of Craig and Benson is to make clear how seriously climate change needs to be taken. The prospect of rapid, non-linear, disruptive climate change is quite real.

Yet resilience is not an adequate replacement for sustainability. The historically grounded understanding of sustainability, which is based on integrated decision making, is not the version of sustainability these critics attack. They take issue with versions of sustainability that are different from those formulated at the 1992 Rio Earth Summit. Meadows correctly states that many people see sustainability as being about keeping what developed countries already have while developing countries catch up, but that is not the understanding of sustainable development articulated at the Earth Summit.

Similarly, there is no warrant in the history of sustainable development for the Craig and Benson 'linguistic' definition of the term as sustaining existing environmental conditions. Their understanding frames sustainability as an environmental goal, not a decision-making framework, which is inconsistent with the history of the term. Moreover, they assert that sustainable development is based on only a single goal - keeping environmental conditions in some baseline or steadystate condition - which contradicts the fact that sustainable development texts endorse a wide variety of different environmental goals, not to mention social and economic development. Finally, there is little evidence in the core sustainability texts of any desire to maintain environmental conditions in their current state. On the contrary, the UNFCCC specifically anticipates the need for adaptation. The goal of the parties to the Convention is to prevent global temperatures from increasing beyond 1.5 to 2.0 degrees Celsius, rather than returning global temperatures to preindustrial levels. The history of biodiversity protection under the CBD has, to a very large degree, been about slowing down the rate of biodiversity loss. Given the enormous environmental losses experienced all over the world in 1992 and today, it was and is unthinkable to endorse a position based on keeping the environment in its current condition.

It is necessary to give greater emphasis to resilience, but it is not appropriate to abandon sustainability. It is far more beneficial to treat both sustainability and resilience as necessary, consistent, and mutually reinforcing. ${ }^{221}$ Indeed, the

220 Ibid., at p. 28.

221 See C. Redman, 'Should Sustainability and Resilience Be Combined or Remain Distinct Pursuits?' (2014) 19(2) Ecology \& Society, pp. 37-44; A. Hecht, J. Fiksel \& M. Moses, 'Working Toward a Sustainable Future' (2014) 10(2) Sustainability: Science, Practice, \& Policy, pp. 65-70 (explaining how federal agencies should foster both sustainability and resilience); H. Jun \& M. Conroy, 'Linking Resilience and Sustainability in Ohio Township Planning' (2014) 57 Journal of Environmental Planning and Management, pp. 904-19 (using a case study of 46 township plans in Ohio to show that communities with comprehensive plans that promote sustainability also exhibit resilience); J. Anderies et al., 'Aligning Key Concepts for Global Change Policy: Robustness, Resilience, and Sustainability' (2013) 18(2) Ecology \& Society, pp. 8-21 (explaining that resilience should inform sustainability decision making); U. Pisano, 'European Sustainable Development Network, Resilience and Sustainable Development: Theory of Resilience, Systems Thinking and Adaptive Governance', ESDN 
sustainability agreements that emerged from the 1992 Rio Earth Summit explicitly include climate change adaptation and resilience as part of sustainability. The inclusion of resilience in the sustainability framework is consistent with the overall integrated decision-making approach on which sustainability is based. That framework encourages decision makers to determine the particular environmentrelated goals, including but not limited to resilience, that are most appropriate for their situation. Sustainable development is also preferable to resilience because it is broader, normative, and more optimistic.

In many cases sustainability requires resilience. To compare, the US Endangered Species Act requires actions to further both the 'survival' and 'recovery' of protected species. ${ }^{222}$ Although there are obvious differences between the two ideas, for over 45 years scientists have generally discovered that there is little difference between the two concepts in their application. Providing for survival necessarily includes providing for foreseeable change in species habitats and the stochastic events which are part of life on the planet, even in the absence of climate change. ${ }^{223}$ Similarly, climate change adaptation, which is built into the UNFCCC, necessarily includes resilience. In fact, resilience works only if it is integrated in a widespread way into public and private decision making - the core feature of sustainable development.

Yet resilience is not the only relevant environmental goal. By itself, resilience does nothing to reduce or remedy environmental problems. Resilience, instead, is about protecting people from the effects of these problems. This is particularly problematic for climate change, the signature resilience issue for Craig and Benson; ${ }^{224}$ resilience says nothing about reducing GHG emissions (or concentrations) in the atmosphere.

Moreover, key principles that support sustainable development are not present in the concept of resilience. The precautionary approach would suggest that both sustainable development and resilience are needed; a resilience-only approach would limit our options, and therefore both the probability and severity of adverse outcomes. Resilience is also contrary to the polluter-pays principle because it does not address the sources or causes of pollution; it addresses only their effects, and says nothing about having the polluters pay for resilience efforts.

Although sustainable development emphasizes the importance of reducing poverty and increasing equity, resilience does not. It is simply about the ability of systems to withstand shocks; it provides no guidance on how that ability should be distributed through the population on an intergenerational or intragenerational basis. This is particularly problematic because climate change from increasing GHG emissions which resilience does not address - is likely to increase global poverty. ${ }^{225}$ If society

Quarterly Report 26, 2012, available at: http://tinyurl.com/ESDN26 (explaining how sustainable development and resilience are mutually reinforcing).

22216 U.S.C. $\mathbb{S} \mathbb{S} 1536(\mathrm{a})(2), 1538(\mathrm{a}), 1533(\mathrm{f})$.

223 F. Cheever, 'The Road to Recovery: A New Way of Thinking about the Endangered Species Act' (1996) 23(1) Ecology Law Quarterly, pp. 1-78, at 13-4.

224 N. 211 above.

225 See, e.g., World Bank, Turn Down the Heat: Why a $4^{\circ} \mathrm{C}$ Warmer World Must be Avoided - A Report for the World Bank by the Potsdam Institute for Climate Impact Research and Climate Analytics (World Bank, 2012). 
puts its resources into resilience rather than sustainability, it is likely that only the rich or well-off will be protected.

While public information, public participation, and access to justice - all underpinnings of democratic governance - are essential for sustainable development, they are absent from the concept of resilience. Yet democratic governance is absolutely essential to address the challenges presented by climate disruption. David Orr points out that coming catastrophes will test our system of governance; only through preserving an effective participatory government, accountable to the people, are we likely to survive with the basic principles of our civilization intact. ${ }^{226}$

To a significant degree, these differences in scope and breadth exist because sustainable development is a normative term directed at improving human freedom, opportunity, and quality of life. Resilience, by contrast, is a descriptive term applicable to a broad range of human and non-human systems. Meadows recognizes that resilience is needed to meet human needs, but it is difficult to see how resilience by itself would help to accomplish the goals of sustainable development. As the late Elinor Ostrom and her colleagues observed: 'Resilience is a system-level concept and is distinct from sustainability in that it is not normative, i.e., it does not include specific choices about performance measures: we seldom hear of sustainable dictatorships, but there are resilient dictatorships' ${ }^{227}$ One might attempt to redefine resilience as a normative term guided by the same principles and goals as sustainable development, but that simply turns a conversation about the proper role of resilience into a question about which label (sustainable development or resilience) one prefers for the same set of ideas. It is much simpler and less confusing to apply sustainable development in a manner that includes resilience goals.

The narrowness of resilience can be illustrated by an analogy with the Cold War. The US and the Soviet Union had thousands of nuclear missiles pointed at each other, and tens of millions of people are likely to have died in the first hour alone if there had been a nuclear war. To prevent catastrophe, both nations took two approaches: (i) preventing the use of these missiles through a variety of diplomatic and political means (including the economic and social development efforts discussed above), ${ }^{228}$ and (ii) civil defence (particularly in the construction of bomb shelters). The US Federal Emergency Management Agency, with roots in the Cold War, still espouses a broad mission to protect American citizens and first responders from 'all hazards'. ${ }^{229}$ If the US had merely employed a resilience approach during that period, it would simply have built bomb shelters. As a result, it would have been more likely to need them.

The analogy with bomb shelters also points to the limitations of resilience as an alternative approach. During the Cold War, a recurring question was whether these

226 D. Orr, 'Governance in the Long Emergency', in E. Assadourian (ed.), State of the World 2013: Is Sustainability Still Possible? (Island Press, 2013), pp. 279-90.

227 Anderies et al., n. 221 above, at p. 11.

228 See text accompanying nn. 51-7 above.

229 US Department of Homeland Security, National Preparedness Task Force, 'Civil Defense and Homeland Security: A Short History of National Preparedness Efforts', Sept. 2006, available at: https://training.fema.gov/EMIWeb/edu/docs/DHS\%20Civil\%20Defense-HS\%20-\%20Short\%20 History.pdf. 
shelters would even protect their occupants, given the enormous destructive power of nuclear weapons. Similarly, it is difficult to specify the minimum conditions of resilience, given the wide range of potential futures that climate change and other environmental problems could bring. ${ }^{230}$ This is particularly true for climate change: an unstable climate will keep changing over time and seriously impede any efforts at harnessing resilience.

The analogy with the Cold War also suggests a deeper point about sustainable development. In the face of seemingly intractable environmental and poverty problems, sustainable development offers people a message of hope and constructive engagement. By contrast, resilience conveys a gritty message about survival and the pointlessness of trying to reduce or eliminate these same problems:

Resilience tacitly suggests that we have acknowledged that survival at the level that we have come to expect and enjoy is no longer possible. Instead, we are resigned to circle the wagons and look for means and methods to survive as best we can for as long as we can. Once we have entered this mind-set, even if it is only through our use of language, sustainability/survival is no longer where we are headed or what we are trying to accomplish. We have created the self-fulfilling prophesy of a path to decline with unknown and unknowable consequences. We have changed the compact that constitutes the values of our civilization. ${ }^{231}$

In 1974, in Lifeboat Ethics: The Case Against Helping the Poor, Garrett Hardin offered a troubling thought experiment to counter the then-prevalent metaphor of 'Spaceship Earth'. He asked us to imagine a lifeboat holding 50 people with a capacity of 60 . In addition, he asked us to imagine another 100 people swimming in the water trying to get into the boat in order to survive. The crisis at hand was the crisis of overpopulation and limited food supply. Hardin suggested that the populations of developed countries with adequate food supplies had reason to deny assistance to the less fortunate:

We are all the descendants of thieves, and the world's resources are inequitably distributed. But we must begin the journey to tomorrow from the point where we are today. We cannot remake the past. We cannot safely divide the wealth equitably among all peoples so long as people reproduce at different rates. To do so would guarantee that our grandchildren and everyone else's grandchildren would have only a ruined world to inhabit. $^{232}$

Hardin's logic applies with equal force to a world facing climate change. Developed countries have the power to adapt and survive, at least in the short term. Many of the less developed countries do not. Hardin endeavoured to blame the crisis of the $1970 \mathrm{~s}$ on undeveloped countries based on their high birth rates. Climate change is more plainly the responsibility of developed countries with their long histories of carbon emissions. We did not choose a lifeboat solution to the problems in the $1970 \mathrm{~s}$. We should not choose a lifeboat solution to our current issues.

\footnotetext{
230 Yanarella \& Levine, n. 172 above, at p. 198.

231 Ibid., at p. 204.

232 Hardin, n. 200 above, at p. 41.
} 
The quest for sustainability may fail. We may be overwhelmed by rapid, non-linear climate change; but we may also succeed, particularly if we accelerate the transition to sustainability. That prospect provides a necessary measure of the hope necessary to motivate action. If we focus on resilience alone, we may not even get that.

\section{CONCLUSION}

In Civilization and its Discontents, written between two catastrophic world wars, Freud expressed persuasively the urgency of changing our ways of thinking if we are to avoid annihilation: 'And now, it seems to me, the meaning of the evolution of culture is no longer a riddle to us. It must present to us the struggle between Eros and death, between the instincts of life and the instincts of destruction, as it works itself out in the human species'. ${ }^{23}$ This same struggle, between the instincts of life and the instincts of destruction, is now occurring between conventional development and sustainable development. One puts civilization at serious risk from widespread environmental degradation and extreme poverty; the other offers the possibility of maintaining and even enhancing human quality of life in harmony with nature.

The policy space created by the concept of sustainable development is being filled by a wide variety of laws, policies, and activities that further social and economic goals while protecting the environment. The understanding of sustainability underlying these laws and activities is the shared creation of millions of practitioners all over the world. Their constant and repeated interactions and experiences refine and improve both understanding and outcomes. There is every expectation that each community will work out the specific meaning of sustainability based on its own history, natural resources, economic situation, and other conditions. Some communities, moreover, emphasize certain aspects of sustainability more than other aspects. Nonetheless, the overall decision-making framework is remarkably similar in all countries, corporations, and NGOs. It is neither realistic nor appropriate to ignore this shared practice and understanding. This understanding of sustainability is not one of many trains that are parked in the station waiting for passengers; the train left the station more than two decades ago.

The task ahead is to craft, adopt, and implement new and modified laws, products and services, and other practices that are not only sensible and ambitious but are also so attractive that they will overcome all the many obstacles to change, including not only opposition but also simple inertia. To accelerate the transition to sustainability, it will be necessary to foster abundance and thriveability, to actually protect and restore the environment, and to be more resilient. All of these require the sustainable development decision-making framework, and none of them can adequately replace it.

No single article can do justice to the enormous and ever-expanding literature of sustainable development in an enormous range of human fields of endeavour. We know these are powerful concepts, and that they have facilitated change at many levels. We also know that they have been intentionally and unintentionally

233 S. Freud, Civilization and Its Discontents (W.W. Norton \& Co., 2005, first published 1930), p. 102. 
misapplied. Both the beneficial effects and the misapplication of sustainable development prompted our effort to foster a shared understanding of its meaning.

Although discussions of terminology can be fundamentally silly, there is no question that continued debate about the meaning of sustainable development, in the broad range of contexts in which it is applied, serves an important purpose. It is only by honestly considering the meaning of the phrase in every context that we can come to any real understanding of its general meaning. To a great degree, the real battles about the meaning of sustainable development and sustainability are fought in specific places and contexts. Under what circumstances can shale gas accelerate the transition to sustainability? ${ }^{234}$ What is required to make sustainable forestry happen on a widespread basis? ${ }^{235}$ Sustainable development provides an essential normative framework setting out basic criteria for making those evaluations. It does not answer all questions and there are frequently several reasonable answers to the same question, but starting in the right place makes better decisions and better laws more likely. Given the opportunities that sustainability provides, and the consequences of getting it wrong, we need to get it right.

234 J. Dernbach \& J. May, 'Can Shale Gas Help Accelerate the Transition to Sustainability?’ (2015) 57(1) Environment: Science and Policy for Sustainable Development, pp. 4-15; see also J. Dernbach \& J. May (eds), Shale Gas and the Future of Energy: Law and Policy for Sustainability (Edward Elgar, forthcoming 2016).

235 Cheever \& Scott, n. 3 above. 